\title{
الترجيح بين مفهومي الموافقة والمخالفة وأثره في استنباط الأحكام الشرعية
}

\section{Ali Khodran Mohammad al-Omari}

King Khalid University - KSA email: handody1111@hotmail.com

المللخص

مـن المسـائل الأصـولية التي تُبحث في بـاب التعـارض والترجيح و هي التيرجيح بـين مفهومي

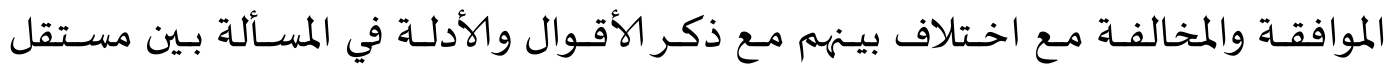

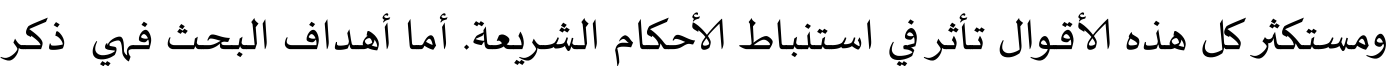
أقـوال العلمـاء في المسـألة، وأدلتهم،بيـان الـراجح مـن تلك الأقوال،توضـيح أثر الخـلاف في

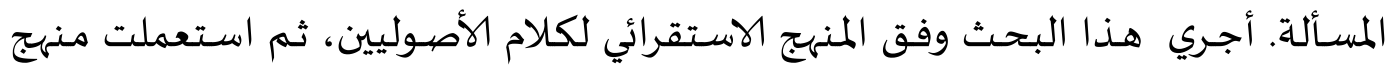

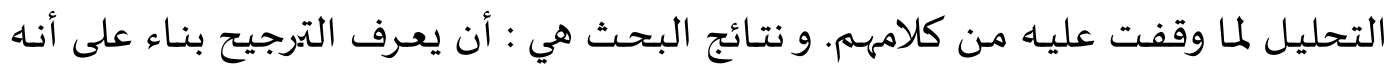
من فعـل المجتهـد، ينقسـم المفهوم إلى مفهـوم موافقـة، الراجح في التيرجيح بـين مفهـومي

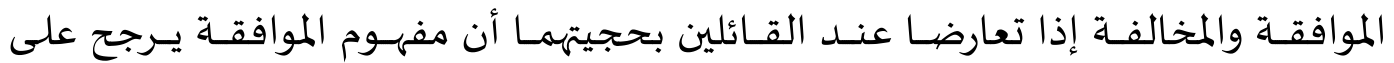
مفهوم المخالفـة إذا كانت دلالته قطعيـة، وأما إذا كانت دلالتـه ظنيـة فإنها لا توجـد قاعدة مطردة في ترجيح أحدهما على الآخر وإنما يكون في كل مسـألة بحسبها. ظهر أثر الخلاف في التيرجيح بـين مفهـومي الموافقـة والمخالفــة إذا كانـت دلالتهمـا ظنيـا في اسـتنبـاط الأحكـام الشـرعية في بعض الفـروع الفقهيـة، ممـا يجعله سـببًا مـن أسبـاب الاختـلاف المحمـود بين العلماء.

الكلمات المفتاحية : التوجيح، مفهوم الموافقة، مفهوم والمخالفة، استنباط الأحكام الشربعة

فإن تعارض دلالات الألفاظ والخلاف بين العلماء في الترجيح بينها باب واسع ينبخي العناية باه؛ لما يترتب عليه من أثر في استنباط الأحكام الشرعية من جهاة، ولالتماس العذربلمن خالف من جهـة أخـرى. ومـن المسـائل الأصـولية التي تُبحثث في بـاب التعـارض والتيرجيح، ولهم تحض بدراسـة

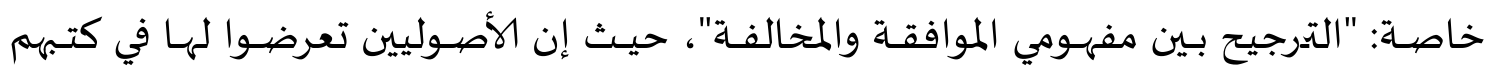
الأصـوليـة، ولكـن مـع اخـتلاف بيـههم في ذكر الأقـوال والأدلـة في المسـألة بـين مسـتقل ومسـتكثر، وعدم ذكر لأثر الخلاف فيها؛ لذا أردت في هذا البحث تتبع كلام الأصهوليين في المسألة، وبيان ما 
وقع فهها من خلاف، وما ترتب عليه من أثر، وأسميته : "الترجيح بين مفهومي الموافقة والمخالفة وأثره في اسـتنباط الأحكام الشـرعية".أما أهـداف البحـث فهي ذكر أقـوال العلمـاء في المســألة، وأدلتهم،بيان الراجح من تلك الأقوال،توضيح أثر الخلاف في المسألة. لم أقف على دراسـة خاصة في الترجيح بين مفهومي الموافقة والمخالفة، وإنما تعرض لها الأصوليون في كتبه في أسطر معدودة'، ومن أوسع من تحدث عن ذلك فيما وقفت عليه الأستاذ العزيز العويد في كتابه "تعارض دلالات الألفاظ والترجيح بينها"حيث عقد لذلك مبحثًا بعنوان: تعـارض مفهـوم الموافقـة ومفهـوم المخالفــة، ويقـع في سـبع صـفحات تقريبًا، ذكـر فيـهـ خـلاف الأصوليين، وأدلهه، ولكن لم يتعرض لأثر الخلاف في استنباط الأحكام الشرعياة، وبالنظر في هذا البحث وما ذكره عبد العزيز العويد يتضح الفرق بينهما.

منهجية البحث

سرت في هذا البحث وفق المنهج الاستقرائي لكلام الأصوليين، ثم استعملت منهج التحليل لما وقفت عليه من كلاههم. قمت بإجراءات البحث على النحو الآتي: 1) جمعت المادة العلمية من مراجعها، ومصهـادرها الأصيلة، ثم وزعتها على مباحث ومطالب،22) عرفت بالقضـايا المتعلقـة بالبحث في اللغة والاصطلاح، وشرحت ما يحتاج إلى شرح،3) ذكرت أقوال العلماء، وما استدل بـهـ أصسحاب كل قـول،4) عزوت الآيـات القرآنيـة إلى سـورها مـع بيـان رقمهـا، وذلك في صـلب البحث،5) خرجت الأحاديث النبوية فإن كان الحديث في الصحيحين أو في أحدهما فإني أكتفيت بتخريجـه منهما، وإن لـم يكن فيهما فإني قمت بتخريجـه من كتب الحـديث المعتمـدة، مـع ذكر أقـوال أهـل العلـم في الحكـم على الحـديث إن وجــت،6) عـزوت نصـوص العلمـاء إلى كتبهم مباشرة، ولم ألجأ إلى الواسطة إلاعند تعذر الأصل،7) عند توثيق المعاني اللغوية اعتمدت على 
HAYULA:Indonesian Journal of Multidisciplinary Islamic Studies, Vol. 2, No.2, Juli 2018 DOI:https://doi.org/10.21009/hayula.002.2.05

كتب اللغة، وذلك بذكر الكتاب، ثم الجزء والصفحةة، وعند توثيق المعاني الاصطلاحية اعتمدت على كتب الفن الخاصة به،88) عند النقل بالنص ذكرت اسم المصيدر، ورقم الجزء، والصفحة، وفي حالة الأخذ بالمعنى ذكرت اسم المصدر مسبوقاً بكلمة "ينظر"، ووضعت رقم الإحالة على آخر الكلام،9) اعتنيت بعلامات الترقيم، ووضعتها في مواضـهها الصسحيحة.أما خطة البحث: قسـمت البحث إلى: مقدمة، وثلاثاة مباحث، وخاتمة.

\section{المبحث الأول : تعريف مفردات العنوان}

المطلب الأول : تعريف الترجيح في اللغة والاصطلاح.

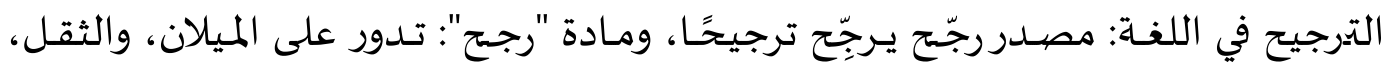

يقـال: "رجــح المييزان"، أي: مـال، و"أرجــح المييزان"، أي: أثقلـه حتى مـال . التيرجيح في الاصـطلاح: للأصوليين في تعريف الترجيح اتجاهان: الاتجاه الأول: تعريف الترجيح بناء على أنه من فعل المجتهد.

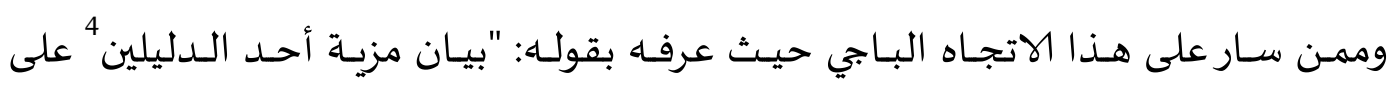
الآخـر" ". والرازي حيـث عرفـه بأنـه: "تقويـة أحسد الطريقين على الآخـر ليعلم الأقوى فيعمل بـه، ويطرح الآخر" . وابن النجار حيث عرفه بقوله: "تقوية إحدى الأمارتين على الأخرى بدليل". الاتجاه الثاني: تعريف الترجيح بناء على أنهاه من صفات الأدلة. وممن سـار على هذا الاتجـاه السمرقندي حيث عرفه بقوله: "أن يكون لأحسد الدليلين زيادة 3 مختار الصحاح (ص/23س0)، ولسان العرب (37/3)، والقاموس المحيط (ص279).

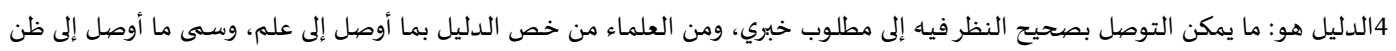

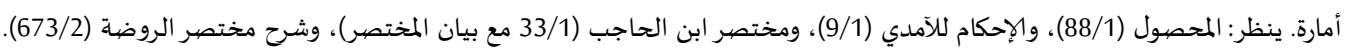
5 الحدود في الأصول (ص79) 6 المحصول (397/5)، وتبعه ابن السبكي في جمع الجوامع (485/3 مع تشنيف المسامع) حيث عرفه بأنه: "تقوية أحد الطريقين"، قال الزركشي: "أي المتعارضين، على الآخر ، ليعمل بالقوية، وهذه عبارة المحصول".

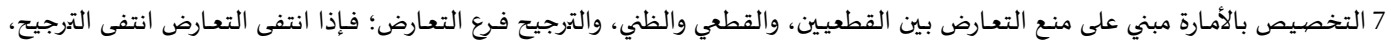

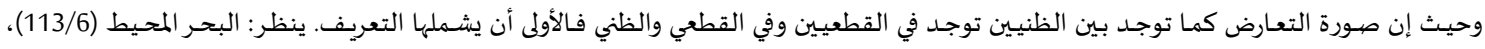

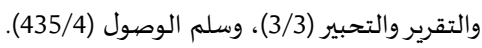
8 شرح الكوكب المنير (616/6). 
قوة مع قيام التعارض ${ }^{9}$ ظاهرًا" . والأمدي حيث عرفها بأنه: "اقتران أحد الصالحين للدلالة على المطلوب، مع تعارضهما بما يوجب العمل به، وإهمال الآخر" .". وابن الحاجب حيث عرفه بقوله: "اقتران الأمارة بما تقوى به على معارضها"12.

وهذان الاتجاهان في تعريف الترجيح وإن كان مآلهما واحدًا؛ لأن المجتهد لا يمكنه أن يبين

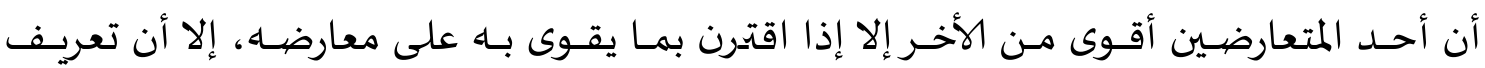
التيرجيح بناء على أنه من فعل المجتهـد أولى؛ لأن اقتران أحد المتعارضين بما يقوى بـه على الآخر يقال لهه رجحان، أو ترجُّح ب. وحيث إن التعارض في هذا البحث بين دلالتي المفهوم، فالأولى في تعريف الترجيح أنه: تقوية أحد الطريقين بما يتقدم بها على معارضه؛ لأن أحد الطريقين يشمل أمورًا منها: التعارض بين الاحتمالات في دليلين، أو في دليل واحد.14. المطلب الثاني: تعريف المفهوم في اللغة والاصطلاح

تعريـف المفهـوم في اللغــة: اسـم "مفعـول" مـأخوذ مـن "فَهـم" بالكسـر، ك"فَرِح" أي: علـم،

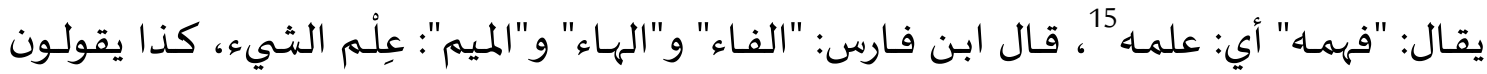
أهلُ اللغة" "16، فيكون معنى "المفهوم": المعلوم. تعريف المفهوم في الاصطلاح: للأصوليين في تعريف

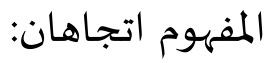

\section{الاتجاه الأول: تعريفه باعتباره مدلولاً.}

وممن سار على هذا الاتجاه إمام الحرمين حيث عرفها بقوله:" ما يستفاد من اللفظ، وهو

9 التعارض عرفه البرزنجي في التعارض والترجيح بين الأدلة الشرعية (23/1) بقوله: "التمانع بين الأدلة الشرعية مُطلقًا بحيث يقتضي أحدهما

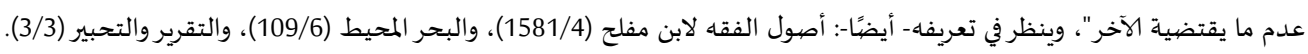

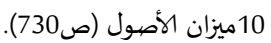

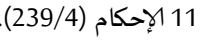

12مختصر ابن الحاجب (239/4). 371/3 مع بيان المختصر)، وبه عرفه ابن مفلح في أصوله (1581/4) (158/4).

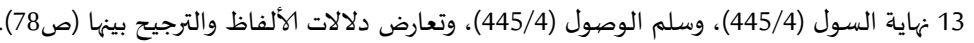

14 التعارض والترجيح بين الأدلة الشرعية (15/4)، وسلم الوصول).

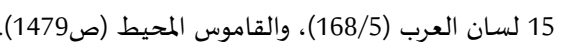

16 مقاييس اللغة (457/4). 
HAYULA:Indonesian Journal of Multidisciplinary Islamic Studies, Vol. 2, No.2, Juli 2018 DOI:https://doi.org/10.21009/hayula.002.2.05

مسكوت عنه،، لا ذكر لله على قضيـة التصريح" .17 والآمدي حيث عرفهـ بأنه:" ما فهم من اللفظ

$$
\text { في غير محل النطق" }
$$

الاتجـاه الثاني: تعريفها باعتباره دلالة.

وممـن سـار على هـذا الاتجـاه ابـن الحاجـب حيث عرفـه بأنـاء: مـا دل عليـه اللفظ لا في

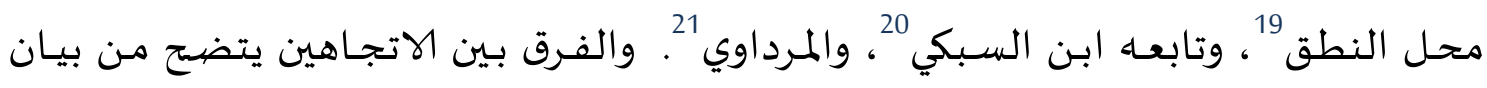
الفرق بين الدلالـة والمدلول. فالدلالة هي: النسبة بين اللفظ والمعنى، ومـن شـأهها أن تسبق المـلولول بهـذا الاعتبـار. والمـدلول هـو: ثمـرة الدلالـة ومـن شـأنها أن يتـأخر عنهـا بهــا الاعتبـار. والـــي يظهـر أن تعريـف المفهـوم باعتبـاره دلالـة أولى في هـــا البحـث؛ لأن التـرجيح بـين المفهومين باعتبـار دلالتهما لا مـدلولهما، فيكون تعريـف المفهوم هـو: "مـا دل عليـه اللفظ في غير محل النطق".

$$
\text { المطلب الثالث: أقسام المفهوم وتعريف كل قسه. }
$$

ينقسم المفهوم إلى قسمين، مفهوم موافقة ومفهوم مخالفة، وبياههما على النحو الآتي: أولا: تعريـف مفهـوم الموافقــة: اختلــف الأصــوليون في تعريـف مفهـوم الموافقــة بسـبـب اخـتلافهم في اشـتراط أولويـة المسـكوت عنـهـ بـالحكم مـن المنطـوق مـن عـدمها. فـذهب بعـض الأصـوليين إلى اشـتراط أن يكون الحكمى في المسـكوت عنــه أولى مـن الحكم في المنطـوق، ومنهم الشـافعي على ما نقله عنـه إمام الحرمين حيث قال: "فمما ذكره [أي: الشـافي] أن قال: المفهوم قسمان، مفهوم موافقة، ومفهوم مخالفة. أما مفهوم الموافقـة فهو ما يـل على أن الحكم في المسكوت عنـه موافق لحكم المنطوق بـه 
مـن الجهـة الأولى..."22، والطوفي حيـث عرفـه بقولـه: "فهـم الحكـم في غير محسل النطق بطريق الأولى"23. وذهب جمهور الأصهوليين 24 إلى عدم اشتراط أولوية المسكوت عنه بالحكم وإنما يكتفى بالمسـاواة، ومنهم الأمدي حيث عرفهه بقوله: "ما يكون مدلول اللفظ في محل السكوت موافقاً لمدلوله في محلـ النطق"25. وابـن الحاجـب حيثث عرفهـ بقولـه: "أن يكون المسـكوت موافقـاً في الحكم" .26. والمرداوي حيث عرفه بقوله: "أن يكون المسكوت موافقًا لمنطوق في الحكم" .27. والـــي يظهـر - والله أعلـمـ- أن مـا ذهـب إليـهـ جمهـور الأصــوليين أولى؛ وذلـك لأن شـرط الأولوية لا وجه له ما دام أن اللغة تقضي بإلحاق المسكوت بالمنطوق في الحكم، سواء أكان أولى أم كان مساوياً، بل في إعمال هذا الشرط إهدار لدلالة اللغة إلا أن يكون ذلك مجرد اصطلاح في أن مفهوم الموافقة هو الأولى فقط من حيث التسمية.28.

وبنـاء عليـه فيكـون مفهـوم الموافقـة هـو: مـا دل عليـه اللفظظ مـن ثبـوت حكـم المنطـوق للمسكوت عنه. سواء أكان المسكوت عنه أولى بالحكم من المنطوق باه، أم كان مساوياً له. ثانيًا: تعريف مفهوم المخالفة: عرّف الأصهوليون مفهوم المخالفة بعدة تعاريف، وهي مبنية على اعتبار المفهوم دلالة أو مدلولاًَ-كما مرّ--، ومنها ما يلي: تعريف إمام الحرمين بأنه: "ما يدل من جهة كونه مخصصياً بالذكر على أن المسكوت عنه مخالف للمخصص بالذكر"29. وتعريف الغزالي بأنه: "الاستدلال بتخصيص الشيء بالذكر على نفي الحكم عما عـداه"30. وتعريف الآمدي بأنه: "ما يكون مدلول اللفظ في محل السكوت فيها

22 البرهان (298/1)

23 شرح مختصبر الروضة (714/2). 24 البحر المحيط (9/4) وفيه: "وهو ظاهر كلام الجمهور من أصحابنا وغيرهم"، والتحبير شرح التحرير (23/681/23). 
HAYULA:Indonesian Journal of Multidisciplinary Islamic Studies, Vol. 2, No.2, Juli 2018 DOI:https://doi.org/10.21009/hayula.002.2.05

مخالفاً لمدلوله في محل النطق" "31. وتعريف ابن الحاجب: "أن يكون المسكوت عنه مخالفاً"32. وهـذه التعـاريف وإن اختلفت في العبارة إلا أنها متفقـة مـن حيـث المعنى، وحيـث سـبق في تعريف المفهوم اختيـار تعريفها باعتبـار كونه دلالة، فيكون تعريف مفهوم المخالفة : ما دل عليـه اللفظ من ثبوت حكم مخالف للمنطوق في المسكوت عنـه.

\section{المبحث الثاني: الترجيح بين مفهومي الموافقة والمخالفة}

\section{المطلب الأول: أقوال العلماء وأدلتهم}

اختلـف الأصـوليون القـائلون بحجيـة مفهـومي الموافقــة والمخالفــة في التيرجيح بينهمـا إذا

تعارضا: بحيث يدل أحدهما على حكم يخالف ما دل عليه الآخر على ثلاثة أقوال:

القول الأول: ترجيح مفهوم الموافقة على مفهوم المخالفة. وبهـ قال جمهور الأصهوليين، من

$$
\text { المالكيةة33، والشافعية،34، والحنابلة .35 واستدلوا على ذلك بما يلي: }
$$

الـدليل الأول: أن مفهوم الموافقـة حجـة عنــ أكثر الأصهـوليين، فلـم يخـالف في حجيتـــ إلا

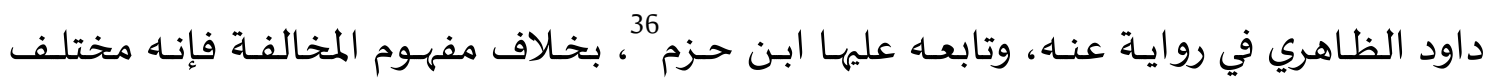
فيـاء ، ولـذا لم يقل بمفهوم المخالفة بعض من قال بمفهوم الموافقةكالحنفيـة33، فرجّح مفهوم الموافقة عليه؛ لضعف مفهوم المخالفة بالخلاف في الاحتجاج باه 39.

الدليل الثاني: أن دلالة مفهوم الموافقة على الحكم الموافق المسكوت عنـه أقوى من دلالة

31 الإحكام (69/3).

32 مختصر ابن الحاجب (444/2 (302/5 مع بيان المختصر).

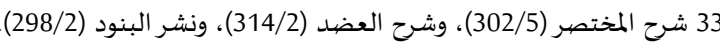

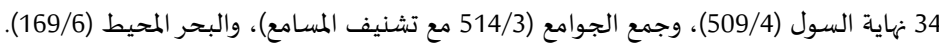

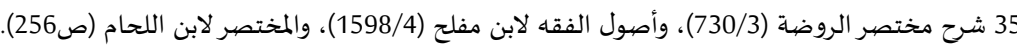

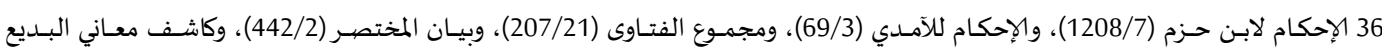

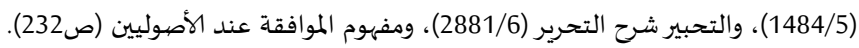

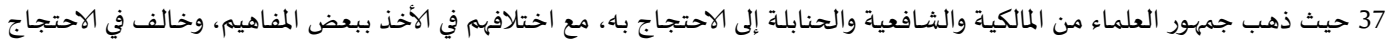

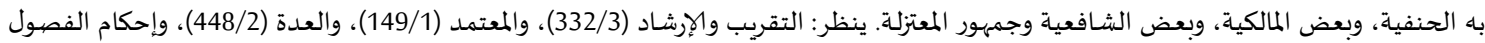

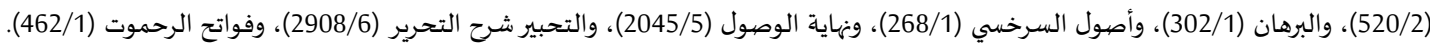

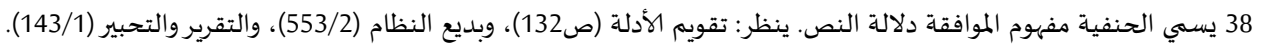

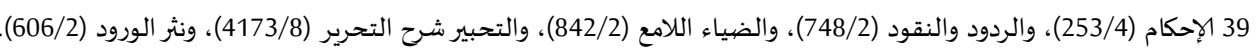


مفهوم المخالفـة على الحكم المخحالف المسـكوت عنـه، ويـل على ذلك اشتراط القـائلين بحجيـة مفهوم المخالفة ألا يكون الحكم المسكوت عنه أولى بالحكم من المنطوق به ب. الدليل الثالث: أن دلالة اللفظ على مفهوم الموافقة أظهر من دلالته على مفهوم المخالفة، وذلك لأن الحكم الثابت بمفهوم الموافقة على القول الراجح ثابت بطريق النص نفساه، لوضوح علته، والوقوف عليها وتعلقها بمجرد سـماع المنطوق بخلاف مفهوم المخالفـة فهو وإن كان ثابتًا بطريق اللفظ عند القائل به، لكناه يحتاج إلى تأمل وروية، فعلى هذا يرجح مفهوم الموافقة على مفهوم المخالفة عند التعارض لقوته ووضوحهه الدليل الرابع: أن مفهوم الموافقة لا يتم الاستدلال به إلا على تقديرات ثلاثة، وهي:1)فهم المقصود من الحكم في محل النطق.2) بيان وجوده في محل السكوت.3) أن اقتضاءه للحكم في

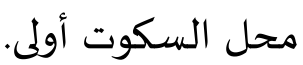
بخلاف مفهوم المخالفـة فإنها لا يتوقف على شيء منها. وما يتم على تقديرات ثلاثة أولى وأرجح مما لا يتم إلا على تقدير واحد (42). القول الثاني: ترجيح مفهوم المخالفة على مفهوم الموافقة. وهذا القول ذكره الآمدي بقوله: "وقد يمكن ترجيح مفهوم المخالفة عليه" "43 وذكره بعض

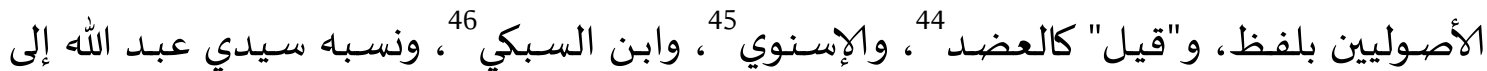
شذوذ"، وذكر الزركشي، ، و المردواي 49 أن صفي الدين الهندي اختاره، ولكن في ذلك نظر؛ لأن

40 شرح العضد (656/3)، والبحر المحيط (169/6)، والتحبير شرح التحرير (387/3)، والمبلق (2894).

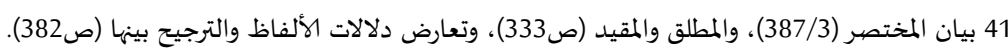
42 شرح المختصر (303/3). 
HAYULA:Indonesian Journal of Multidisciplinary Islamic Studies, Vol. 2, No.2, Juli 2018 DOI:https://doi.org/10.21009/hayula.002.2.05

صفي الدين في نهاية الوصول 50 لم يجزم بشيء، وإنما قال بعد أن ذكر أن مفهوم الموافقة راجـح على مفهوم المخالفـة: "ويمكن أن يرجح مفهوم المخالفـة عليـه"، والذي صـرح بـاه في الفائق 51 هو ترجيح مفهوم الموافقة علياء، حيث قال: "ومفهوم الموافقة راجح على مفهوم المخالفة، لأن دلالته قوية، ولذا حجيته متفق عليها". واستـلوا على ذلك بما يلي:

الدليل الأول: أن فائدة مفهوم المخالفة تأسيس حكم جديد؛ لأنه يفيد حكمًا مخالفًا لما

دل عليه المنطوق، بخلاف مفهوم المخالفة، فإن فائدتا التأكيد؛ لأنه يفيد حكمًا موافقًا لما دل عليه المنطوق. ومثال ذلك: أن مفهوم المخالفة في قوله: (وفي صلدقة الغنهم في سائمتها إذا كانت أربعين إلى عشرين ومائة شاة...) أفاد حكمًا جديدًا وهو عدم الزكاة في المعلوفة، وهو مخالف لما دل عليه المنطوق، فنوع الحكم فيهما مختلف. بخلاف مفهوم الموافقة، فنوع الحكم في المنطوق والمفهوم واحد، فتحريم الضرب والتأفيف في قوله تعالى لفَلا تَقُلن لَهُمَا أُفٍِ نوعهما واحد، وهو تحريم الإيذاء، فيكون تأكيدًا لما دل عليه المنطوق. والتأسيس أصل، والتأكيد فرع، فكان لهذا مفهوم المخالفة أولى مناه وأرجح '53 ورد هذا الدليل: بأن كلا من مفهوم المخالفة والموافقة يفيد التأسيس 54، قال العبادي مبينًا ذلك: "غاية الأمر أن ما تفيده المخالفة مخالف للحكم المنطوق، وما تفيده الموافقة موافق له"(55). الدليل الثاني: أن مفهوم المخالفة مقدماته أقل، وذلك لأنه لا يتوقف على فهم المقصود من الحكم في محل النطق، ولا على بيان وجوده في محل السكوت، بخلاف مفهوم الموافقة، وما كان مقدماته أقل كان أولى وأرجح .56.ويمكن رد هذا الاستدلال بما يلي:

$$
\begin{aligned}
& 50 \text { التحبير شرح التحرير (3709/9). } \\
& 51 \text { التحبير شرح التحرير (425/4). } \\
& 52 \text { أخرجه البخاري في صحيحها (449/1) كتاب الزكاة- باب زكاة الغنم- رقم (1454). } \\
& 53 \text { الإحكام (253/4)، ونهاية الوصول (3709/9)، وشرح العضد (656/3)، وحاشية البناني على شرح المحلي على جمع الجوامع (567/2). }
\end{aligned}
$$

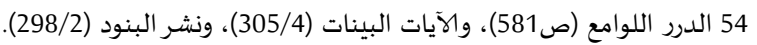

$$
\begin{aligned}
& 55 \text { الآيات البينات (305/4). } \\
& 56 \text { نهاية الوصول (3709/9)، وشرح العضيد (305/4). (35/3)، وتحفة المسؤول (316/4). }
\end{aligned}
$$


أولاً: أنه معارض بما ذكره أصحاب القول الأول بأن مفهوم الموافقة أرجح لأنه يتم على

$$
\text { تقديرات أكثر. }
$$

ثانيًا: أن كثرة التقديرات أو قلتها لا أثر له في الترجيح، ويؤيد ذلك أن من الأصوليين من ذكر هذا الدليل على وجه آخر، وهو: أن مفهوم المخالفة يتم على تقديرات أكثر فكان أرجح من مفهوم الموافقة لأنها يتم على تقديرات أقل 57 قال الأمدي: "أن مفهوم الموافقة لا يتم إلا بتقدير فهم المقصود من الحكم في محل النطق، وبيان وجوده في محل السكوت، وأن اقتضاءه للحكم في محل السكوت أشد. وأما مفهوم المخالفة فإنه يتم بتقدير عدم فهم المقصود من الحكم في محل النطق، وبتقدير كونه غير متحقق في محل السكوت، وبتقدير أن يكون أولى بإثبات الحكم في محل السكوت، وبتقدير أن يكون لله معارض في محل السكوت. ولا يخفى أن ما يتم على تقديرات أربعة، يكون أولى مما لا

$$
\text { يتم إلا على تقديرواحد" }
$$

$$
\text { القول الثالث: أنه لا يرجح أحدهما على الآخر. }
$$

وهذا القول ذكره الشوكاني 59، ولم ينسبه لأحد. ولعله يستدل له بما ذكره الأستاذ

الدكتور عبد العزيز العويد من عدم ظهور دليل يرجح به أحد المفهومين على الآخر، فبقي التعارض بينهما إلى أن يرجح أحدهما بدليل من خارج.60. المطلب الثاني: الترجيح

الذي يظهر- والله أعلم- أن الترجيح بين مفهومي الموافقة والمخالفة مبني على نوع دلالة مفهوم الموافقة من حيث القطعية والظنية، حيث إنه ينقسم إلى قسمين: 
HAYULA:Indonesian Journal of Multidisciplinary Islamic Studies, Vol. 2, No.2, Juli 2018

DOI:https://doi.org/10.21009/hayula.002.2.05

مفهوم موافقة دلالته قطعية، وهو ما كان التعليل فيه بالمعنى لا يحتمل غيره، وكان وجوده في المسكوت عنه كذلك. ومفهوم موافقة دلالته ظنية: وهو ما اختل فيه أحد الأمرين السابقين (61) وبناء عليه فإذا كانت دلالة مفهوم الموافقة قطعية فإنه يرجح على مفهوم المخالفة، وذلك لما يلي:

أولاً: لما ذكره أصحاب القول الأول في أدلتهم من كون مفهوم الموافقة متفقًا عليه، وأن دلالتاه أقوى من مفهوم المخالفة، وهذا يراد باه ما كان دلالتـ قطعية. ثانيًا: أن مفهوم الموافقة إذا كانت دلالته قطعياة، فإناه يرجح على مفهوم المخالفة؛ لأن دلالته ظنية، وقد ذكر العلماء أن القطعي لا يعارض الظني؛ لانتفاء الظن في مقابلة القطع، فيكون القاطع هو المعمول باه، والظن لغوًا .62.

وإذا كانت دلالة مفهوم الموافقة ظنية فالذي يظهر- والله أعلم- أنه لا يرجح أحدهما على الآخر؛ كقاعدة مطردة، وإنما يكون الترجيح بحسب ما يظهر لكل عالم في كل مسألة، وذلك لتطرق الاحتمال في الدلالة، ولاختلاف أفهام العلماء فيها، قال ابن تيمياة: "فإن جهات دلالات الأقوال متسعة جدًا، يتفاوت الناس في إدراكها, وفهم وجوه الكلام بحسب منح الحق سبحانه ومواهبه" ، ويتضح ذلك بما سيأتي في المبحث الآتي، وهو: أثر الخلاف في استنباط الأحكام الشرعية.

\section{المبحث الثالث: أثر الخلاف في استنباط الأحكام الشرعية}

بناء على ما سبق في ذكر الأقوال والراجح منها فلا يظهر أثر الخلاف إذا كانت دلالة مفهوم الموافقة قطعية؛ لأناه يرجح على مفهوم المخالفة، وذلك باتفاق، ومن الفروع الفقيهة الدالة على

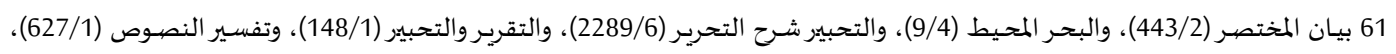

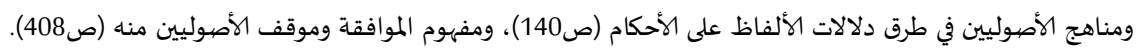

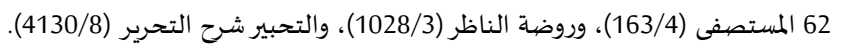
63 رفع الملام عن الأئمة الأعلام (ص29). 
اتفق العلماء على منع بيع المصحف للكافر، وذلك استدلالا بمفهوم الموافقة من قوله : (لا تسافروا بالقرآن، فإني لا آمن أن يناله العسدو) ،6 ورجحـوا ذلك على مفهوم المخالفة، وهـو جواز بيعه، وذلك لكون دلالته على الحكم الموافق قطعيـة؛ حيث نص في الحـديث على المعنى الذي لأجله منع من السفر بالقرآن إلى أرض العدو، وهو مخافة أن يناله أذى كاستخفافهم بـه وامتهانهم إياه، وهذا المعنى متحقق في بيع المصحف من الكافر، لتمكناه من الاستهانة باه، فكان

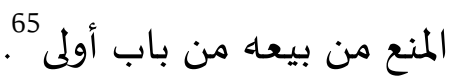
قال ابن حجر: "واستدل باه على منع بيح المصحف من الكافر لوجود المعنى المذكور فيه وهو التمكن من الاستهانة به ولا خلاف في تحريم ذلك"66. ثانيًا: حكم إحراق مال اليتيم. اتفق العلمـاء على تحريم إحراق مال اليتيم، وذلك استـلالا بمفهوم الموافقهـ من قولهـ

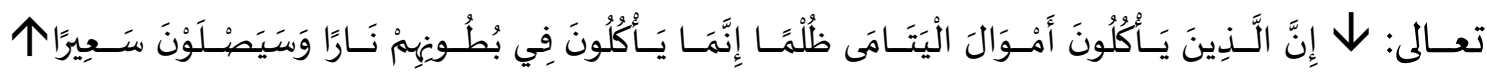
[النساء/10]، ورجحوا ذلك على مفهوم المخالفة، وهو جواز ذلك، وذلك لكون دلالته على الحكم الموافق قطعيـة، حيث إن المعنى الذي لأجلها منع من أكل مال اليتيم ظلمًا هـو إتلافهـ بغيروجهـ حق، وهو موجود في إحراق ماله .67. أمـا إذا كانت دلالــة مفهـوم الموافقـة ظنيـة فبإن أثـر الخـلاف يظهـر في اسـتنباط الأحكام

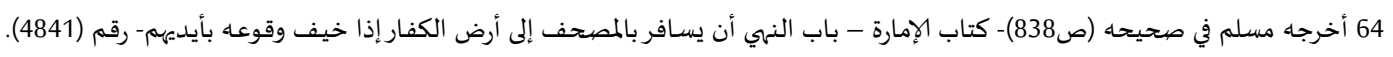

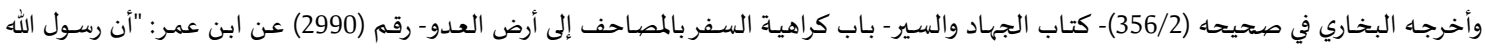

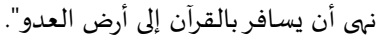
65 المغني (386/6)، والمجموع (135/6) (135/6)، والدر المختار (صان (441)، وشرح مختصر خليل للخرشي (10/5). 66 فتح الباري (134/6).

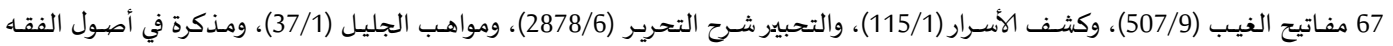

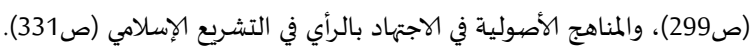


HAYULA:Indonesian Journal of Multidisciplinary Islamic Studies, Vol. 2, No.2, Juli 2018

الشرعية؛ لأن الترجيح بين مفهومي الموافقة والمخالفة إذا تعارضا يكون في كل مسألة بحسب ما يترجح عند كل عالم- كما مرّ- ولذا نجد من يرجح في فرع فقهي مفهوم الموافقة، وفي آخر مفهوم المخالفة، بل نجد في الفرع الفقهي الواحد روايتين في مذهب واحد، وكل رواية مبنية على ترجيح أحد المفهومين على الآخر، ومن الفروع الفقهية ما يلي 68:

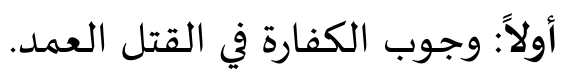

اختلف العلمـاء في حكم الكفـارة في القتل العمـد، وممـا اختلفوا في الاستـلال بـه قولـه

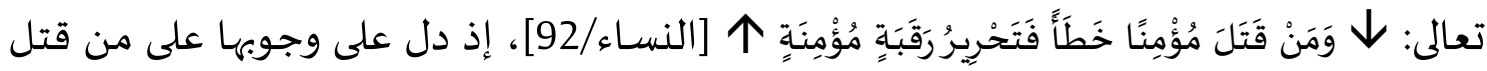
عمدًا بمفهوم الموافقة، وعلى عدم وجوبها علياء بمفهوم المخالفة. ولما كانت دلالته على وجوبها ليست قطعيـة؛ لأنها محتملة حيث إن المعنى الذي وجبت الكفـارة لأجلـه في القتـل الخطأ متردد بين أن يكون: رفع الأثم، أو التغلـيظ في القتل، حصـل التعارض بين مفهومي الموافقة والمخالفة 69؛ وبناء عليها اختلف العلمـاء في ترجيح أحدهما على الآخر.

فـذهب الشـافعية ${ }^{70}{ }^{7}$ بمفهوم الموافقة، وهو: أن الكفارة وجبت في قتل الخطأ، وهو أخف حالا من قتل العمد، لأنه لا قود فيـه والإثم فيـه أخف، والدية محققة فإذا وجبت فيها الكفارة فلأن تجب في قتل العمد الذي هو أعظم إثمًا، وأكبر جرمًا، وحاجته إلى تكفير ذبنه أعظم أولى، وأرجح.

68 لم أتوسع في ذكر الخلاف في الفروع الفقهية؛ لأن ذلك غير مراد، وإنما المراد بيان أثر الخلاف في الترجيح بين المفهومين في استنباط الحكم

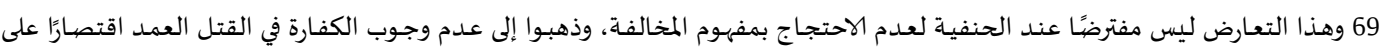

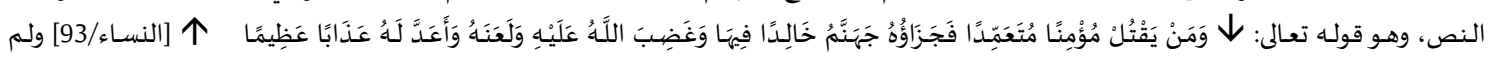

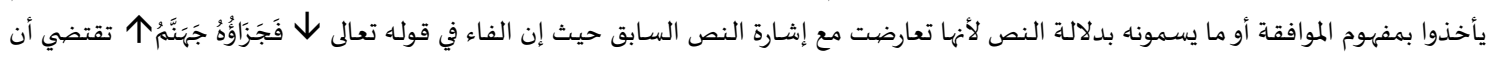

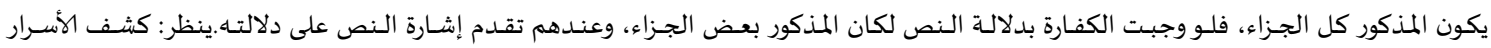

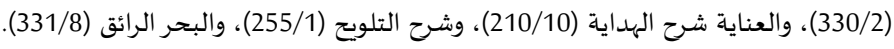

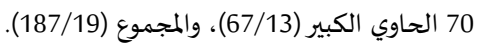
71 المغني (226/12)، والإنصاف (67/13)، والمجيدع (136/10). 


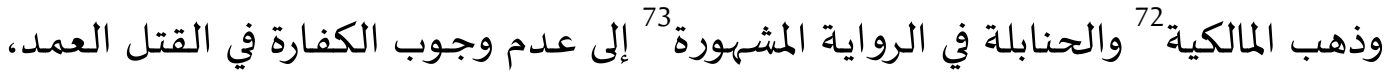

أخـذا مـن مفهوم المخالفـة وهـو: أن الكفـارة وجبت في القتل الخطأ، لأنها تكفر مـا يقابلهـا مـن الإثم، وهو إثم خفيف تزيله الكفارة؛ لأن الاعتداء فيه غيز مقصود، ولكنها لا يخلو من تفريط، بخلاف القتل العمد فإنه أعظم إثمًا وأكبر جرمًا من أن يكفر 74. ثانيًا: حكم قضاء الصلوات التي أخرجها عن وقتها عمدًا.

اختلف العلمـاء في حكم قضـاء الصلوات التي أخرجها عن وقتها عمدًا، وممـا اختلفوا في

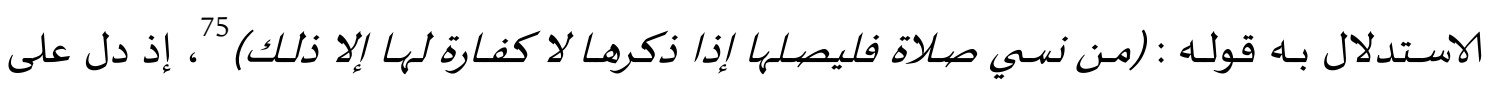
وجوب قضائها على من تركها عمدًا بمفهوم الموافقة، وعلى عدم وجوبها عليه بمفهوم المخالفة. ولما كانت دلالته على وجوبها ليست قطعية؛ لكونها محتملة كما في آية قتل الخطأ حصل التعارض بين مفهومي الموافقة والمخالفة 76. قال القاضي عياض: "فالخلاف في القضاء في العمد كالخلاف في الكفـارة في قتـل العمـد، والخـلاف فهيها انبنى على الخـلاف على ما فى هـذا الحـديث المتقدم، والآية المتقدمة من دليل الخطاب أو من مفهوم الخطاب"77. وبنـاء عليه اختلف العلماء في ترجيح أحدهما على الآخر. فذهب المالكية

72 المعونة على مذهب عالم المدينة (1355/3))، وشرح مختصر خليل (137/10)، وكناف (426/12).

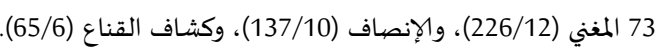

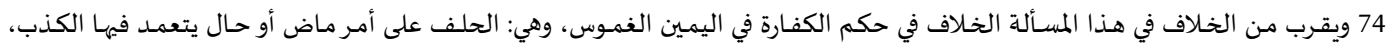

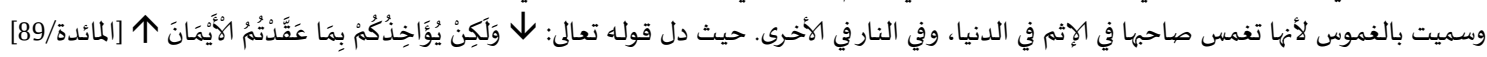

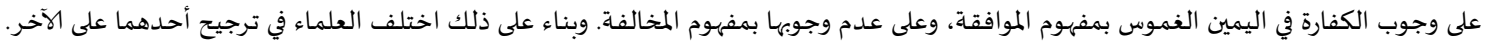

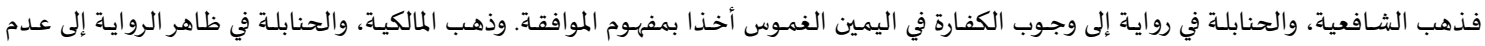

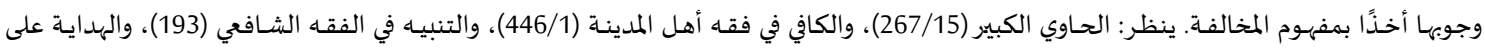

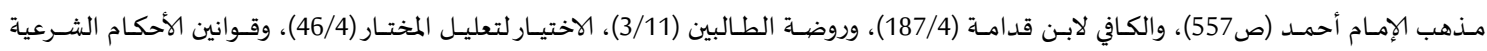

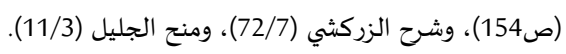

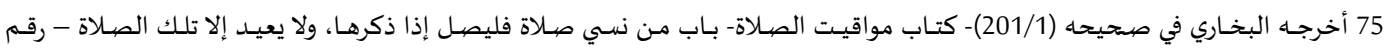

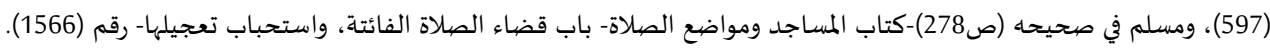

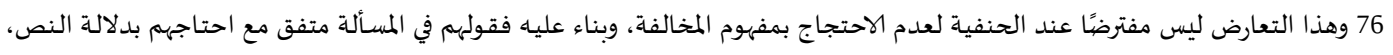

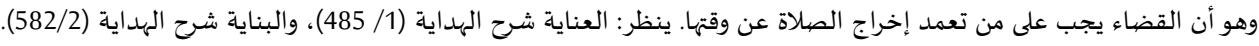
77 إكمال المعلم شرح صحيح مسلم (670/2)

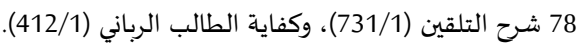

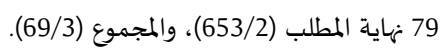


HAYULA:Indonesian Journal of Multidisciplinary Islamic Studies, Vol. 2, No.2, Juli 2018 DOI:https://doi.org/10.21009/hayula.002.2.05

والحنابلة 80 إلى وجـوب القضياء على من تعمد إخراجها عمدًا وذلك أخـذا بمفهوم الموافقة، وهو: أن القضــاء إذا وجـب على مـن تـرك الصـلاة بعـذر كالنسـيان، مـع كونـهـ لا لـوم عليـه ولا إثـم فقضاؤها على من تعمد إخراجها عن وقتها يكون أولى وأرجح؛ لكونه فعل ذنبًا يحتاج إلى تكفير.

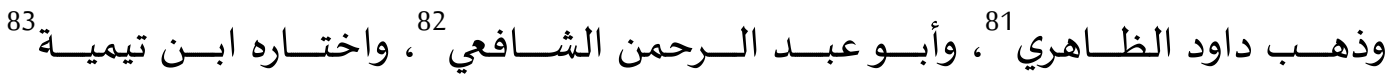

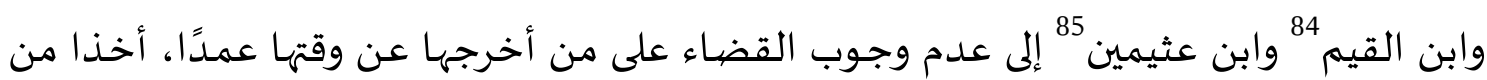
مفهوم المخالفـة، وهـ أن القضياء إنما وجب على الناسي لأنـاه معـذور، ولا إثم عليـه، بخلاف من أخرجها عمدًا فإن فعله أعظم إثمًا وأكبر جرمًا من أن يكفر بقضائها 86. ثالثًا: حكم السلم 87 الحال. اختلف العلماء في حكم السلم الحال، ومما اختلفوا في الاستدلال باه قوله: (من أسلف في شيء ففي كيل معلوم، ووزن معلوم، إلى أجل معلوم) 88، إذ دل على جـواز السلم الحال بمفهوم الموافقة، وعلى عدم جوازه بمفهوم المخالفة. ولما كانت دلالة مفهوم الموافقة على جـوازه ليست قطعيـة؛ لأنها محتملة، حيث إن المعنى الذي شرع لأجله السلم المؤجل متردد بين أن يكون: لنفي الغرر، أو للرفق بالأمة،حصل التعارض

80 الإنصاف (442/1)، والشرح الممتع (137/2).

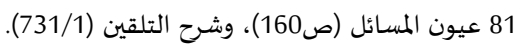

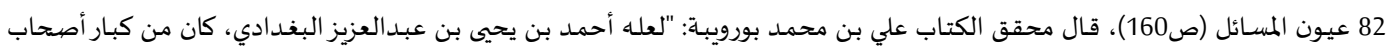

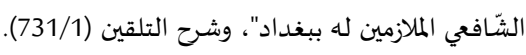
83 الفتاوى الكبرى (377/5). 84 مدارج السالكين (380/1).

85 مجموع الفتاوى (103/22)، والشرح الممتع (137/2).

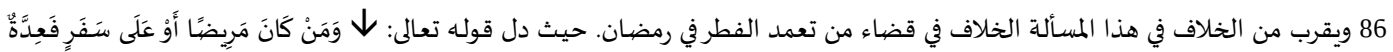

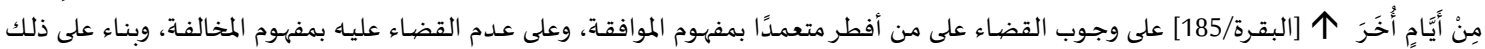

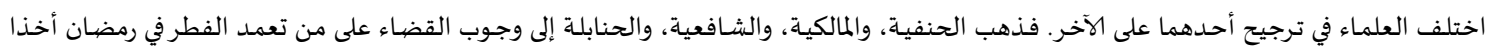

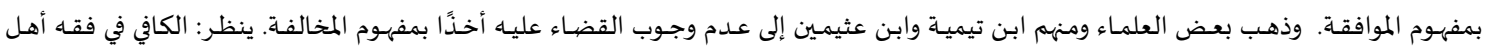

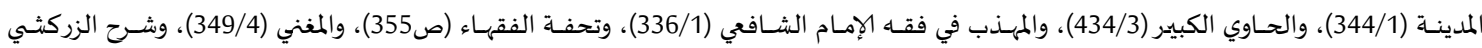

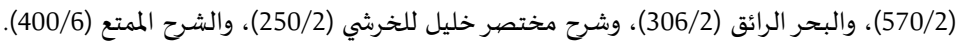

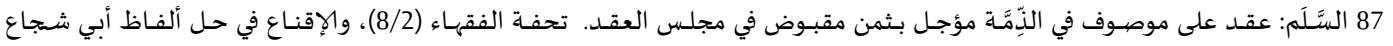
(291/2)، والشرح الكبير للدردير (195/3)، ومطالب أولي النهى (208/3).

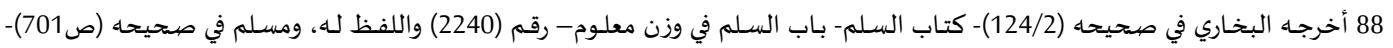

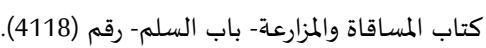


بين مفهومي الموافقة والمخالفة؛8 وبناء عليه اختلف العلماء في ترجيح أحدهما على الآخر. فالمشهـور عـن المالكيـة 90 وكـذلك الحنابلـة 91 عـدم جــواز السـلم الحـال أخــا مـن مفهوم المخالفـة حيث نص الحـديث على جـواز السـلم في المؤجل، لكونـهـ أرفق بالأمـة، فــل بمفهومـهـ المخالف على عدم جوازه في الحال؛ لانتفاء الرفق؛ لأن الرفق لا يحصل إلا بالأجل.

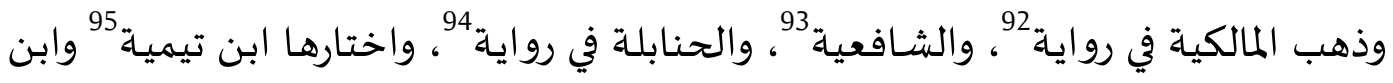
القيم 96 إلى جواز السلم في الحال إذا كان في ملكه وذلك أخذا بمفهوم الموافقة، وهو: أن السلم إذا جاز في المؤجل وفيه غرر، فجوازه في الحال مع انتفاء الغرر من باب أولى.

الخاتمة

في خاتمة هذا البحث أذكر أهم النتائج التي توصلت إلهها، وهي ما يلي:

أولاً: الأولى أن يعرف الترجيح بناء على أنه من فعل المجتهد، وأنه: تقوية أحد الطريقين بما يتقدم باه على معارضها.

ثانيًا: المراد بالمفهوم في هذا البحث: ما دل عليه اللفظ في غير محل النطق، وذلك بناء على

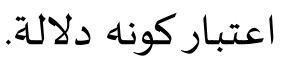

ثالثًا: ينقسم المفهوم إلى مفهوم موافقة، وهو ما دل عليه اللفظ من ثبوت حكم المنطوق

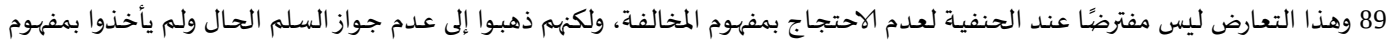

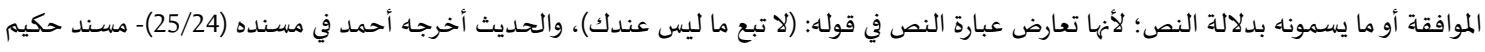

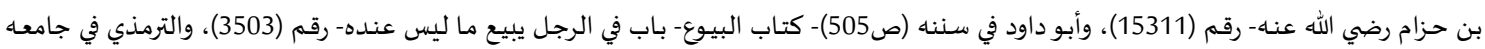

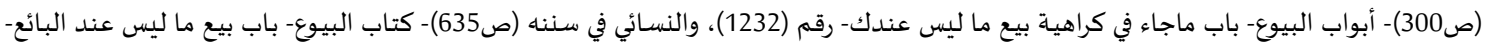

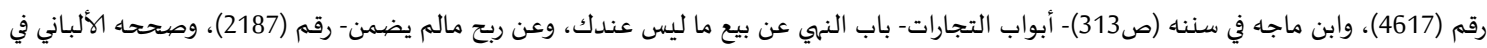

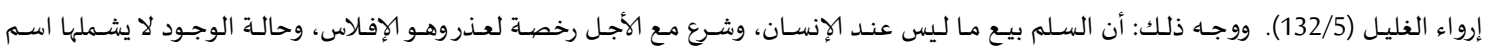

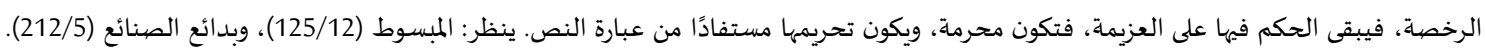

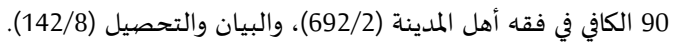

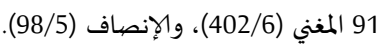

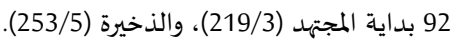

93 روضة الطالبين (7/4)، ومغني المحتاج (219/3)، والذخرة (8/3).

94 الفروع (326/6)، والإنصاف (98/5) (98/5).

95 الإنصاف (98/5).

96 ينظر: زاد المعاد (812/5). 
HAYULA:Indonesian Journal of Multidisciplinary Islamic Studies, Vol. 2, No.2, Juli 2018 DOI:https://doi.org/10.21009/hayula.002.2.05

للمسكوت عنـاه، ومفهوم مخالفـة، وهو ما دل عليـه اللفظ من ثبوت حكم مخالف للمنطوق في المسكوت عناه.

رابعًا: الراجح في الترجيح بين مفهومي الموافقة والمخالفة إذا تعارضا عند القائلين بحجيتهما أن مفهوم الموافقة يرجح على مفهوم المخالفة إذا كانت دلالتـ قطعية، وأما إذا كانت دلالته ظنية فإنه لا يوجد قاعدة مطردة في ترجيح أحدهما على الآخر وإنما يكون في كل مسألة بحسبها. خامستَا: ظهـر أثر الخـلاف في التيرجيح بـين مفهـومي الموافقــة والمخالفــة إذا كانت دلالتهمـا ظنيـة في اسـتنباط الأحكام الشـرعية في بعضض الفـروع الفقهيـة، ممـا يجعلـه سـببًا مـن أسـباب الاختلاف المحمود بين العلماء. المصيادر والمراجع أبـو الوليـد البـاجي، إحكام الفصـول في أحكام الأصـول، تحقيـق: عبدالمجيـد التركي، دار الغـرب

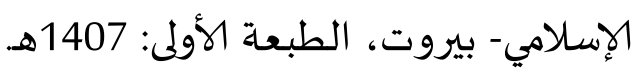

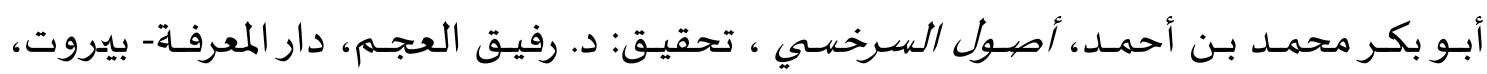
الطبعة الأولى: 1418هـ احني

أبـو بكر بن مسـعود بن أحمد الكاسـاني الحنفي ،بـائع الصنائع في ترتيب الشـرائع لعلاء الدين،

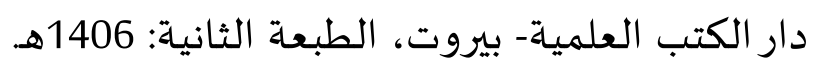

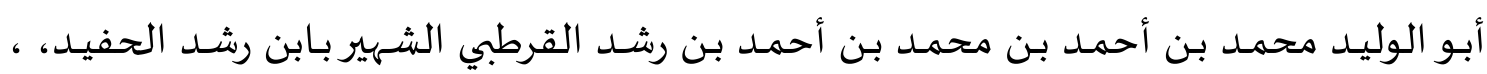

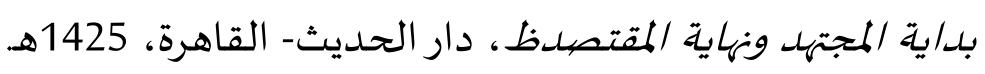

أبـو الوليـد محمـد بـن أحمـد بـن رشـد القرطبي، البيان والتحصيل والشــح والتوجيه والتعليل

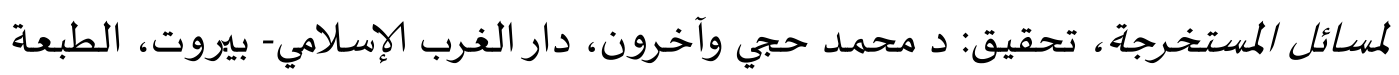
الثانية: 1408 هـ

أبو الحسن علي بن سليمان المرداوي الحنبلي، التحبيزشـح التحرير، تحقيق: د. عبدالرحمن بن

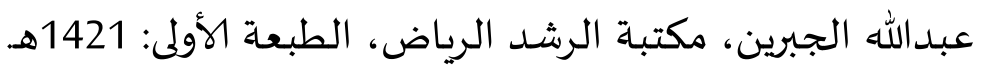

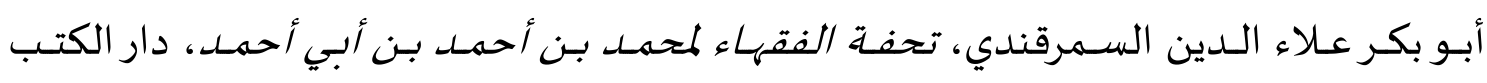

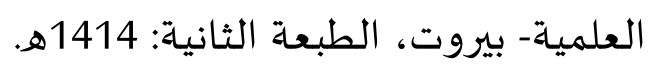




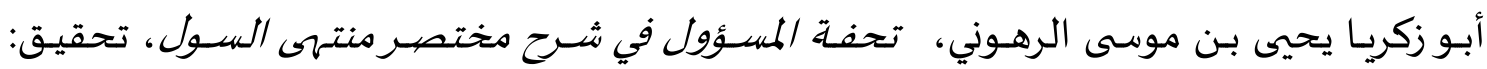

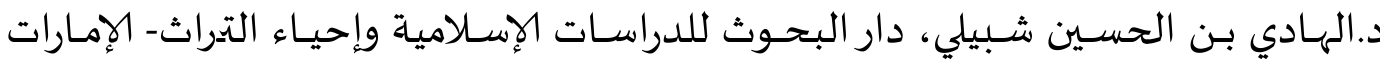

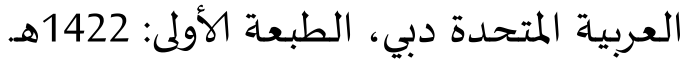

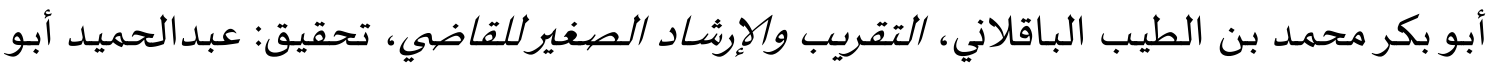
زنيد ،مؤسسة الرسالة- بيروت، الطبعة الأولى: 1413هـ.

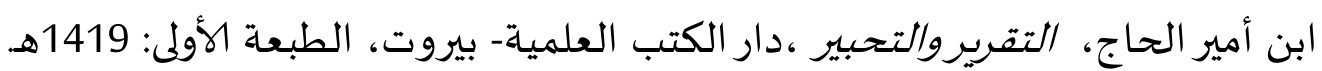

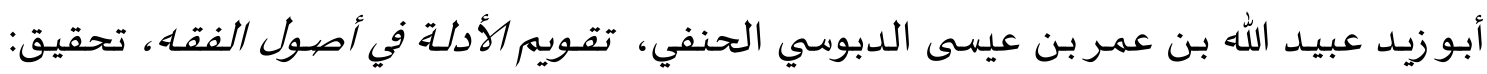

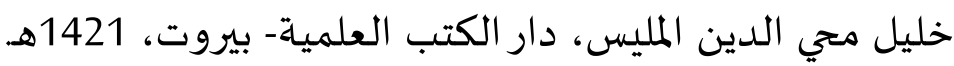
أبو اسحاق إبراهيم بن علي بن يوسف الشيرازي، التنبيه في الفقه الشافعي، عالم الكتب. أبو الوليد سليمان بن خلف الباجي الأندلسي، المتوفى سنة 474هـ، الحسدود في الأصهول، تحقيق:

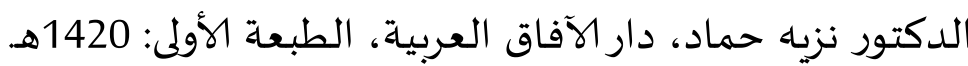

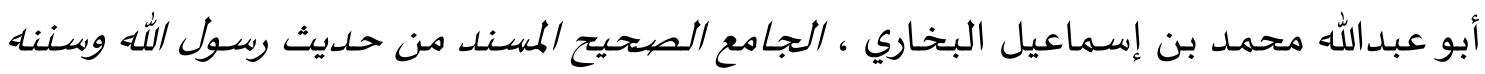
وأيامه ،المكتبة السلفية- القاهرة، الطبعة الأولى: 1400هـ السهاعي السعائ.

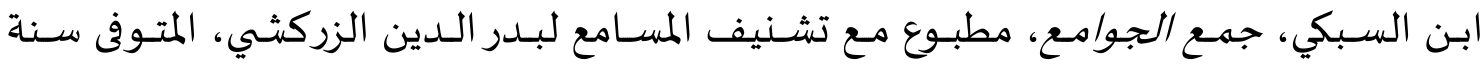

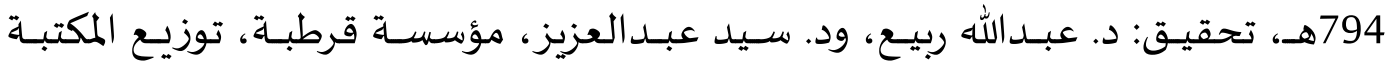
المكية- مكة المكرمة، الطبعة الأولى: 1419هـ دونه

أبو العباس شهاب الدين أحمـد بن إدريس بن عبدالرحمن المالكي، الشهير بالقرافي، النذخيرة،

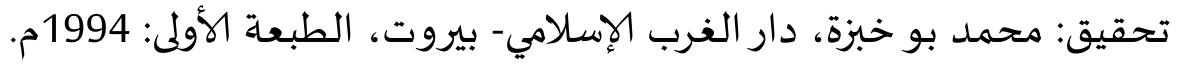

أبو العباس أحمد بن عبدالحليم بن عبدالسلام بن عبدالله ابن تيمية الحراني الحنبلي

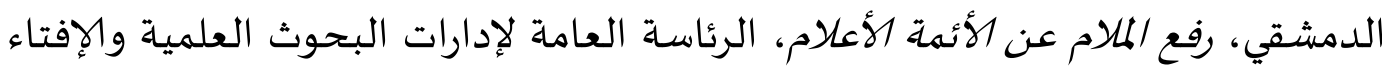

$$
\text { والدعوة والإرشاد- الرياض، 1403هـ. }
$$

أبـو زكريـا محيي الدين يحيى بـن شـرف النووي، روضـة الطالبين وعمدة المفتـين، تحقيق: زهير الشاويش، المكتب الإسلامي- بيروت، الطبعة الثالثة، 1412هـ.

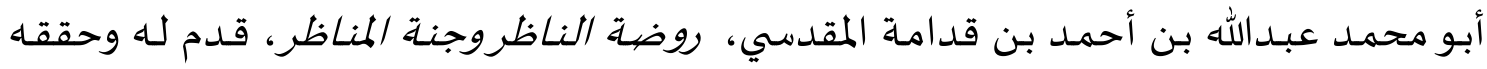

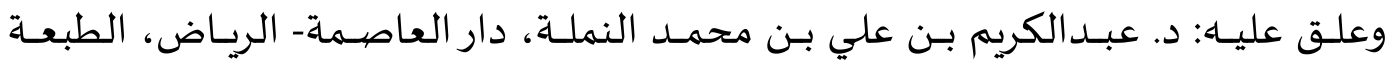

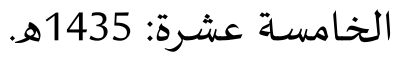

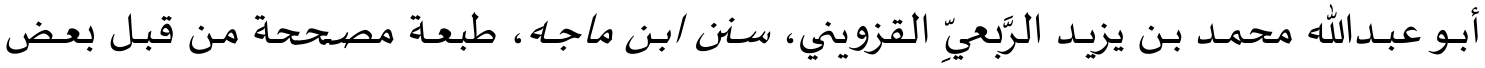

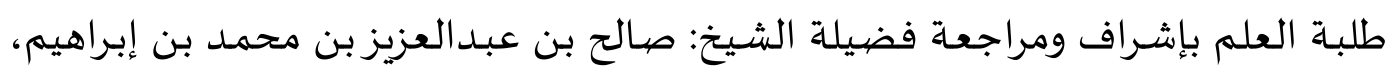

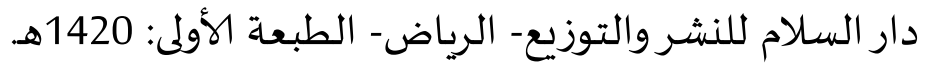


HAYULA:Indonesian Journal of Multidisciplinary Islamic Studies, Vol. 2, No.2, Juli 2018 DOI:https://doi.org/10.21009/hayula.002.2.05

أبو عبـدالرحمن أحمـد بن شعيب بن علي النسـائي، سنن النسيائي الصغنرى، طبعة مصححة من قبل بعض طلبـة العلهم بإشـراف ومراجعـة فضيلة الشيخ: صـالح بن عبـدالعزيز بن محمـد بن إبراهيم، دار السلام للنشر والتوزيع- الرياض- الطبعة الأولى: 1420هـ.

أبو عبدالله محمد بن علي بن عمر التَّمِيهي المازري المالكي، شـرح التلقين، تحقيق الشيخ محمَّد

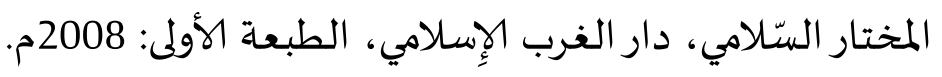

أبـو الثنـاء قطب الدين محمـود بـن مسـود بـن مصلح الشـيرازي، شــح مختصير منتههى الوصهول

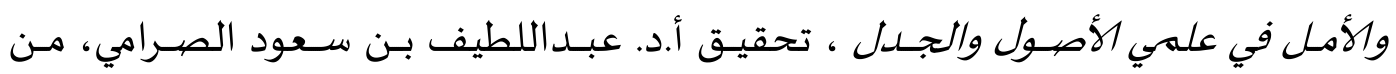
مطبوعات جامعة الإمام محمد بن سعود الإسلامية- الرياض، 1433هـ. أبو يعلى الحنبلي، العدة في أصول الفقه، تحقيق: د. أحمد سير المباركي، الطبعة الثانية: 1410هـ. أبـو محمـد عبـدالوهاب بـن علي بـن نصـر الثعلبي البغـدادي المالكي،عيـون المسبائل، تحقيق: علي

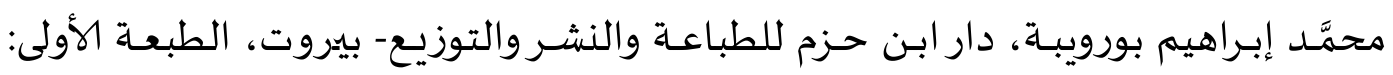

1430هـ

صفي الدين محمد بن عبدالرحيم الهندي،الفائق في أصهول الفقه، تحقيق: د. علي بن عبدالعزيز

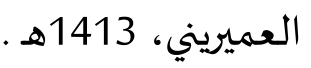

أبو العباس أحمد بن عبدالحليم بن تيمية الحراني، الفتاوى الكابزى، تحقيق: محمد عبـدالقادر

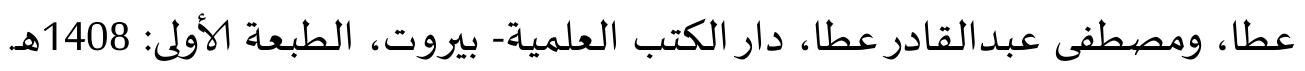
أبو محمد موفق الدين عبدالله بن أحمد بن محمـد بن قدامة الجماعيلي المقدسي ثم الدمشقي

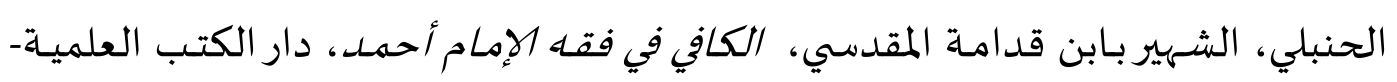

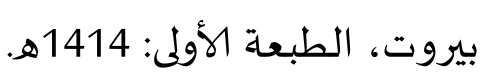

أبو عمر يوسف بن عبدالله بن محمد بن عبدالبر بن عاصهم النمري القرطبي ،الكافي في فقه أهل

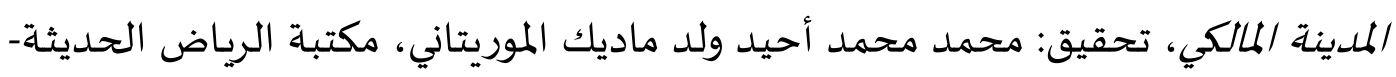
الرياض، الطبعة الثاني: 1400هـ.

أبو العباس تقي الدين أحمد بن عبدالحليم الحراني، مجموع الفتاوى، جمع وترتيب عبدالرحمن

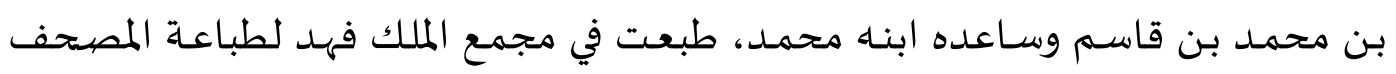
الشـريف- المدينــة المنـورة، تحست إشــراف: وزارة الشـؤون الإسـلامية والأوقـاف والــدعوة

$$
\text { والإرشاد، 1424هـ. }
$$

أبو زكريا محيي الدين يحيى بن شرف النووي، المجموع شرح المهنب، دار الفكر- بيروت. أبـو زيـد القيرواني لأبي الحسـن المالكي، كفاية الطالب الرباني لرسـالة، تحقيق: يوسـف الشـيخ محمد البقاعي، دار الفكر - بيروت، 1412هـ. 
أبو الحسن علي بن محمد بن محمد بن حبيب البصري البغدادي، الشههير بالماوردي المتوفى سـنة 450هـ، لحاوي الكبيزفي فقـه مندهب الإمام الشـافعي، تحقيق: علي محمد معوض وعادل أحمد عبدالموجود، دار الكتب العلمية، بيروت- لبنان، الطبعة الأولى: 1419هـ أبو عمرو عثمان ابن الحاجب المالمكي، مختصر المنتههى الأصهولي، مطبوع مع بيان المختصر لشمس

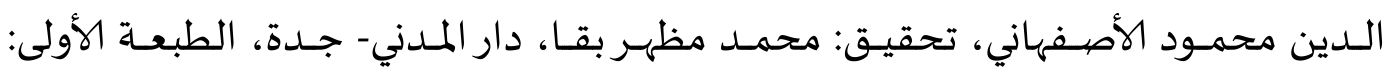
1406هـ 1 1 1

أبـو محمـد عبـدالله بـن أحمــ بـن قدامـة، المفنـي، تحقيق: د. عبــالله بـن عبدالمحسـن التركي ود. عبــالفتاح محمــد الحلـو، دارعـالم الكتـبـ الريـاض، توزيـع وزارة الشــؤون الإســلاميـة والأوقاف والدعوة والإرشاد بالمملكة العربية السعودية، الطبعة الثالثة: 1417هـ. أبـو عبــالله محمـــ بـن عمـر بـن الحسـن بـن الحســن التيهي الرازي الملقـب بفخـر الـدين الرازي خطيب الري، مغاتيح الغيب، دار إحياء التراث العربي- بيروت، الطبعة الثالثة: 1420هـ. خليفة بابكر حسن، مفهوم الموافقة عند الأصهوليين ، بحث منشور في مجلة الشريعة والدراسـات الإسلامية بجامعة الكويت، المجلد الخامس، العدد 10، 1988مـ

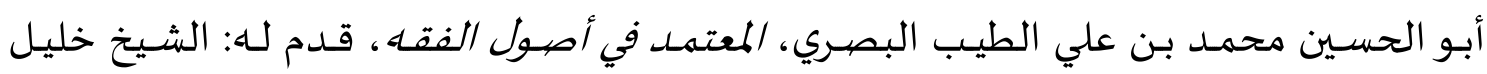
المَيس،، دار الكتب العلمية- بيروت، الطبعة الأولى: 1403هـ أبو استحاق إبراهيم بـن علي بـن يوسـف الشيرازي ، المهندب في فقة الإمام الشـافعي، دار الكتب

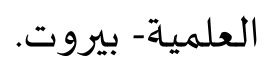

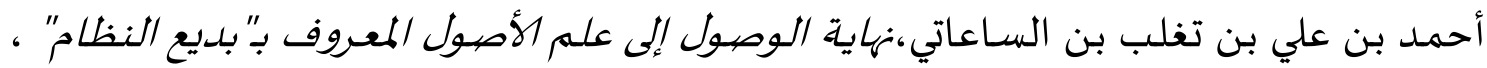
تحقيـق: د. سـعـد بـن غريـر بـن مهـــي السـلمي، جامعــة أم القـرى معهـــ البحــوث العلميـة وإحياء التراث الإسلامي- مكة المكرمة، 1418هـ ـ. أبي الحسين أحمد بن فـارس بن زكريا، مقاييس اللغـة ،تحقيق: عبدالسـلام محمد هارون، شركة الرياض للنشر والتوزيع- الرياض، دار الجيل- بيروت.

أبو حامد محمد الغزالي، المستصيف، دراسة وتحقيق: د. حمزة بن زهير حافظ. أحمـد بـن حنبـل، مسـنـل الإمام أحمـل ، المشـرف العـام على إصــار هـذه الموسـوعـة د. عبــالله بـن عبـد المحسـن التركي، مؤسســا الرسـالة- بيروت، توزيـع وزارة الشـؤون الإسـلامية والأوقـاف والدعوة والإرشاد بالمملكة العربية السعودياة، الطبعة الثانية: 1429هـ موسي أحمـد بـن علي بـن حجـر العسـقلاني، فتح الباري شـرح صسحيح البخـاري ، تحقيق: محسب الـدين الخطيب، دار المعرفة- بيروت.

أحمـــــن عبـدالرحمن بـن موهـى بـن عبــ الحـق الزليطنى القـروى المعـروف بـ"حلولو"،الضيـياء 
HAYULA:Indonesian Journal of Multidisciplinary Islamic Studies, Vol. 2, No.2, Juli 2018 DOI:https://doi.org/10.21009/hayula.002.2.05

اللامع شـح جمع الجوامع، تحقيق: نـادي فرج درويش العطار، مركز ابن العطار للتراثالقاهرة، الطبعة الأولى: 1425هـ.

أحمد بن محمد الدردير، الثشح الكبير ، تحقيق: محمد عليش، دار الفكر- بيروت أحمد بن إسماعيل الكوراني،الدرر اللواهع في شـرح جمع الجواهع، تحقيق: إلياس قبلان التركي، دار صادر- بيروت، الطبعة الأولى: 1428هـ

أحمد بن قاسم العبادي الشافعي، المتوفى سنة 994هـ.الويات البينات على شرح جمع الجبوامع ، ضبطة: زكريا عميرات، دار الكتب العلمية- بيروت، الطبعة الأولى: 1417هـ

الإمام مالك بن أنس أبي محمد عبـدالوهاب بن علي بن نصر الثعلبي البغـدادي المالكي ، المعونة

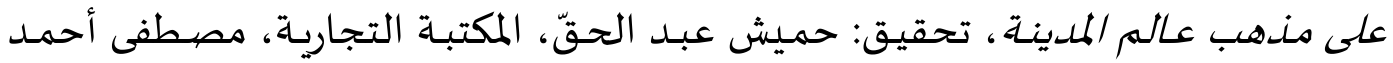
الباز - مكة المكرمة

إمـام الحـرمين الجـويني، البرهـان في أصــول الفقــه ،تحقيـق: عبــالعظيم الـديب، دار الأنصـارالقاهرة، الطبعة الثانية: 1400هـ.

الإمام أبي عبدالله أحمد بن محمدل بن حنبل الثيباني، تحقيق: عبداللطيف هميم، وماهر ياسين

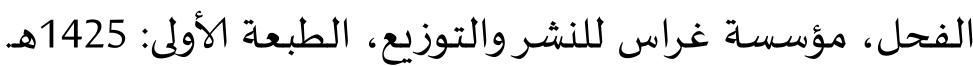

بــدر الــين الزركثـي، تشــيف المســامع بجمهـع الجوامسع، تحقيـق: د. عبــالله ربيـع، ود.سـيد عبدالعزيز، مؤسسـة قرطبة، توزيع المكتبة المكية- مكة المكرمة، الطبعة الأولى: 1419هـ بلدر الدين محمد بن بهادر الزركشي، البحر المحيط في أصبول الفقـه قام بتحريره: د.عمر سليمان

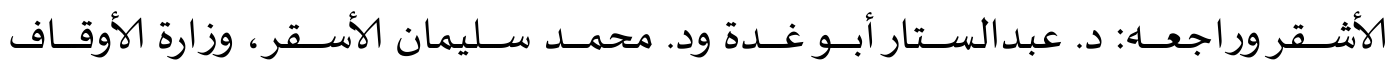

والشؤون الإسلامية- الكويت، دار الصفوة بالغردقة، الطبعة الثانية: 1413هـ. جمال الدين عبدالرحيم الإسنوي، نهاية السـول في شـح منهاج الأصهول، عالم الكتب جمال الدين محمد بن مكرم الافريقي المصري،لسان العرب لابن منظور أبي الفضل، دار صيادرربيروت، الطبعة الأولى: 1997م.

حمـد بن حمـدي الصيّاعدي، المطلق والمقيل وأثرهما في اختلاف الفقهاء، الناشـرعمـادة البحث العلمي بالجامعة الإسلامية بالمدينة المنورة، الطبعة الأولى: 1423هـ.

خليفـة بـابكر الحسـن، منـاهج الأصـوليين في طـق دلالات الولفـاظ على الأحكام، مكتبـة وهبـةالقاهرة، الطبعة الأولى: 1409هـ.

زين الدين بن إبراهيم بن محمـد، المعروف بابن نجيم المصـري ،البحـر الرائق شـح كنز الدقائق، دار الكتاب الإسلامي- بيروت. 
سـليمان بن الأشـعث بن إستحاق الأزدي السجستاني، سنن أبي داود، طبعـة مصسححة من قبل

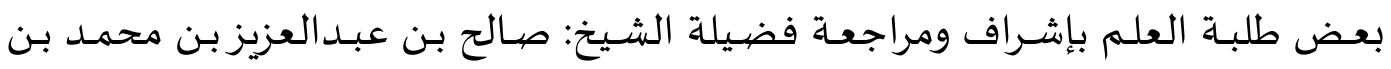

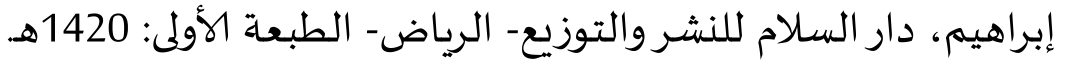

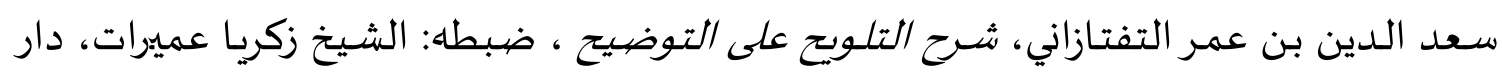
الكتب العلمية- بيروت، الطبعة الأولى: 1416هـ

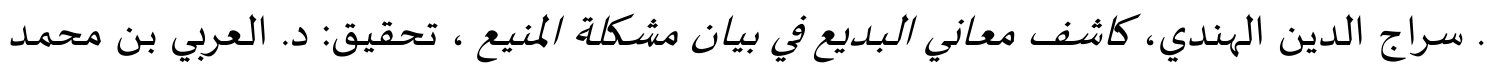

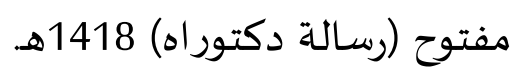

صفي الدين محمد بن عبدالرحيم الهندي، المتوفى سنة 715هـ، نهاية الوصهول في دراية الوصهول،

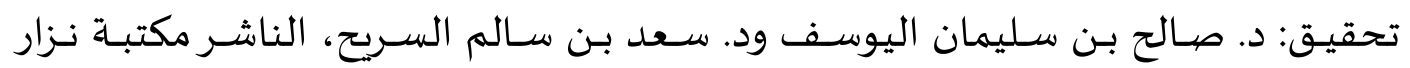
مصطفى الباز- مكاة المكرمة، الطبعة الثانية: 1419هـ

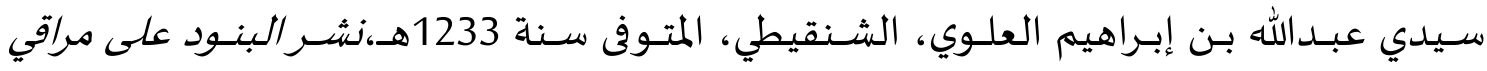

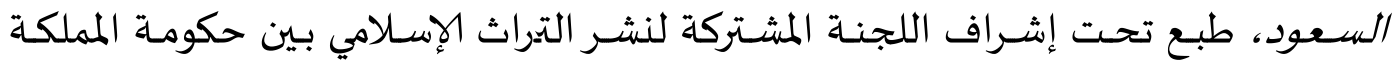

$$
\text { المغربية، وحكومة دولة الإمارات العبية المتحدة. }
$$

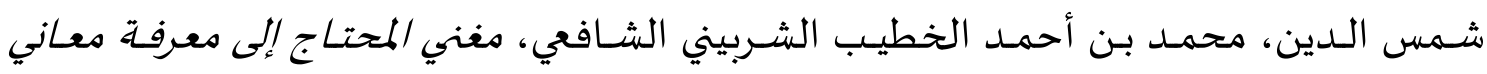

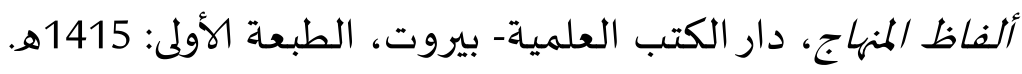

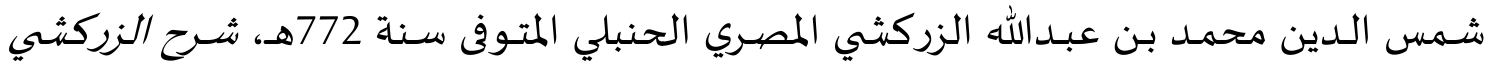

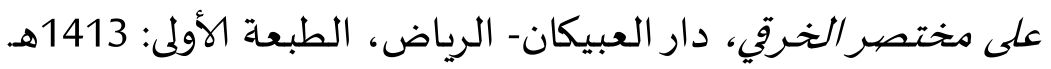

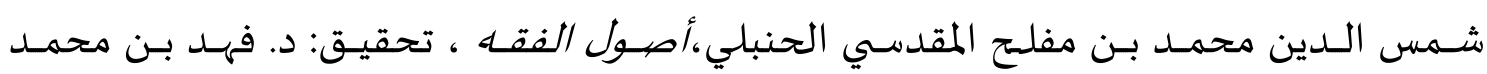
السدحان، مكتبة العبيكان- الرياض، الطبعة الأولى: 1420هـ الطئ

شـمس الدين محمـود الأصفهاني، بيان المختصـرشسر مختصر /بن الحاجب، تحقيق: محمـد

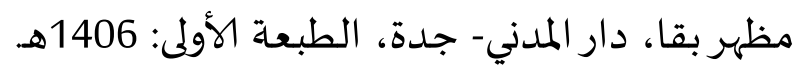

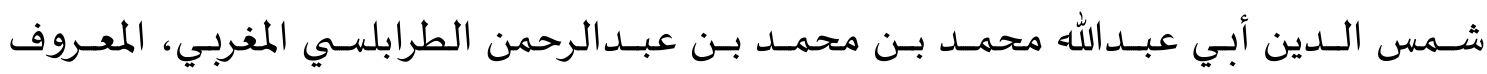

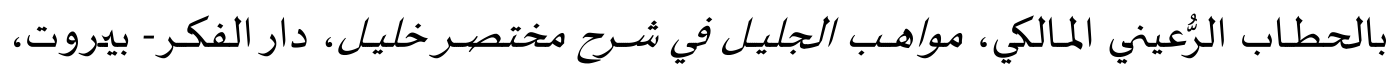

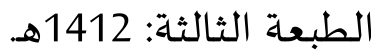

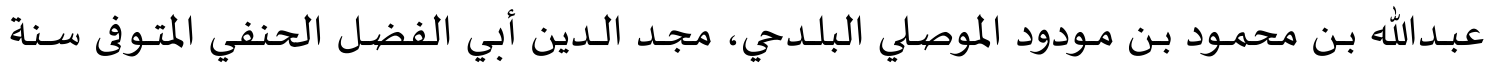

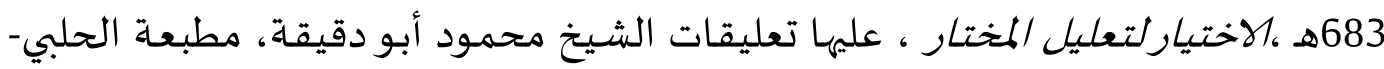
القاهرة -وصورتها دار الكتب العلمية - بيروت- تاريخ النشر: 1356هـ

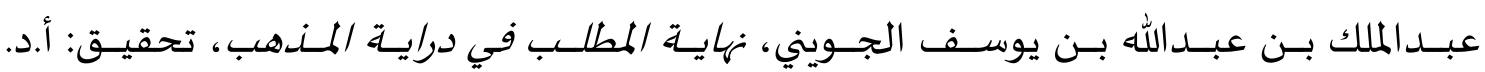

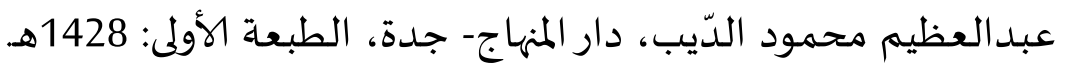


HAYULA:Indonesian Journal of Multidisciplinary Islamic Studies, Vol. 2, No.2, Juli 2018 DOI:https://doi.org/10.21009/hayula.002.2.05

عبدالرحمن بن جـاد الله البناني، حاشية البناني على شـرح الجالال، دار الكتب العلميـة- بيروت،

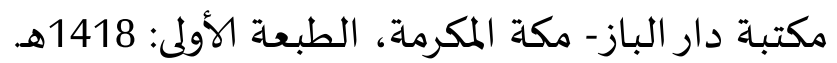

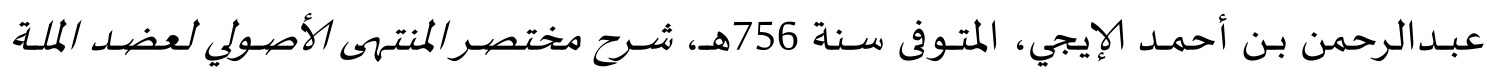
والسلـين، تحقيـق: محمــد حسـن محمــد حسـن إســماعيل، دار الكتـب العلميـة- بيـروت، الطبعة الأولى: 1424هـ

عبداللطيف عبدالله عزيز البرزنجي، التعارض والتيرجيح بين الأدلة الشسرعية ، دار الكتب العلميةبيروت، 1417هـ

عبـدالعزيز بـن محمـد العويـد، تعـارض دلالات الولفـاظ والتيرجيح بينها دراســة أصـولية تطبيقية مقارنة ، مكتبة دار المنهاج- الرياض، الطبعة الأولى: 1431هـه

عبدالوهاب بن عبدالله الرسيني،مفهوم الموافقة وموقف الأصهوليين منـه- دراسة أصهولية مقارنة،

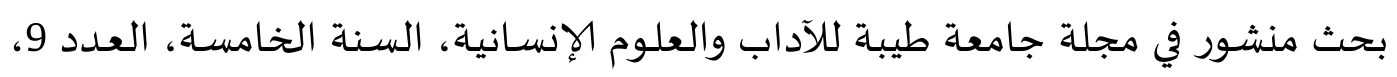
1437 هـ

علاء الـدين أبي الحسـن علي بن سـليمان المرداوي الدمشـقي الصـالحي الحنبلي ــ،الإنصياف في معرفة الراجح من الخالاف ،دار إحياء التراث العربي- البيروت، الطبعة الثانية.

علاء الدين عبدالعزيز بن أحمد البخاري ،كشف الأسرارعن أصول فخر الإسلام، وضيع حواشية:

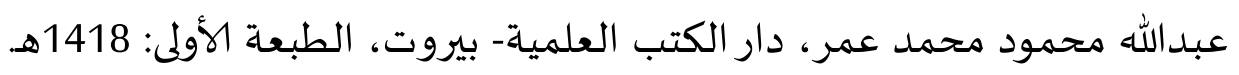

علي بن محمد الآمدي، الإحكام في أصهول الأحكام ، تعليق: عبدالرزاق عفيفي، المكتب الإسلاميبيروت، الطبعة الثانياة: 1402هـ

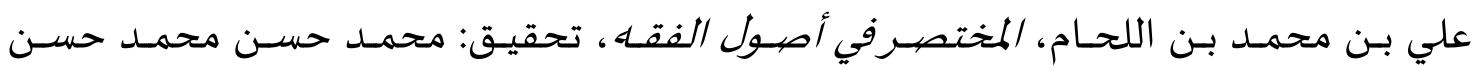

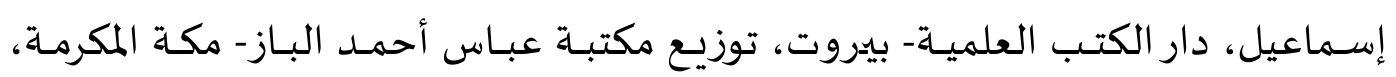

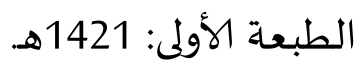

عيسى محممد بن عيسى بن سـورة ابن موسى الترمذي، جامع التومنذي ،طبعة مصححة من قبل

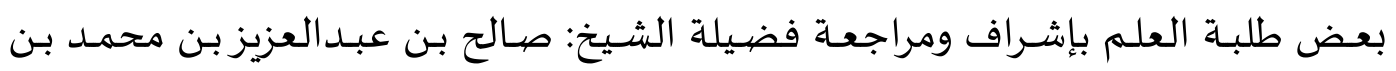
إبراهيم، دار السلام للنشروالتوزيع- الرياض- الطبعة الأولى: 1420هـ

فخر الدين محمد بن عمر الرازي، المحصيول في علمر الأصهول ، تحقيق: د. طه العلواني، مؤسسـة الرسالة- بيروت، الطبعة الثانية: 1412هـ.

قاضیى عيـاض بـن موسـى بـن عيـاض بـن عمـرون اليحصبي السـبتي، أبي الفضـل،إكمال المعلـم

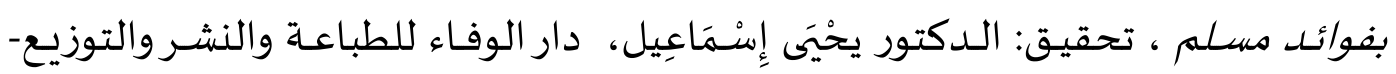
مصر، الطبعة الأولى: 1419هـ. 
محفوظ بن أحمد بن الحسن، أبي الخطاب الكلوذاني، الهد/ية على منهب

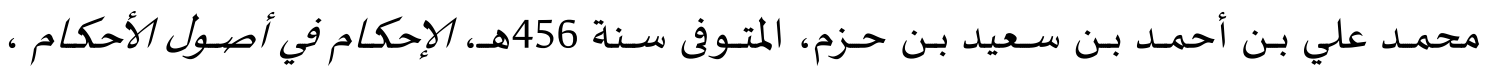
تحقيق: د. محمود حامد عثمان، دار الحديث- القاهرة، الطبعة الأولى: 1419هـ

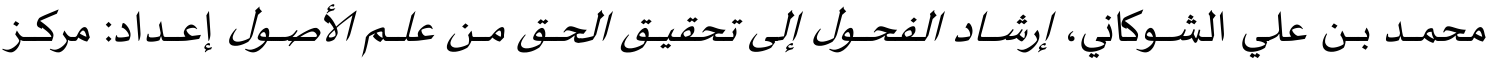

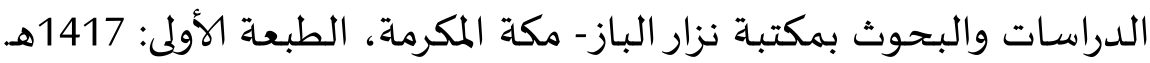

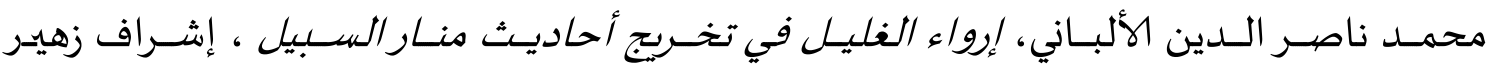
الشاويش، المكتب الإسلامي- بيروت، الطبعة الثانية: 1405 هـ. محمــد بـن أحمـــ الشـربيني، الإقناع في حـل ألفـاظ، تحقيـق: مكتـب البحـوث والدراسـات، دار

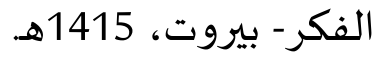

محمـد أديب الصـالح، تفسير النصـوص في الفقه الإسبلامي، المكتب الإسـلامي- بيروت، الطبعـة

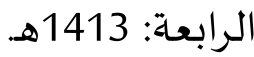

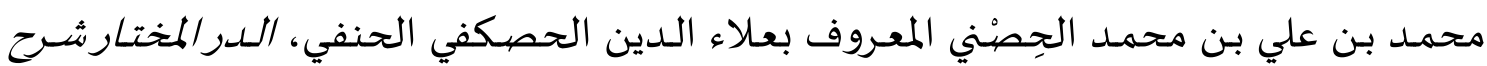

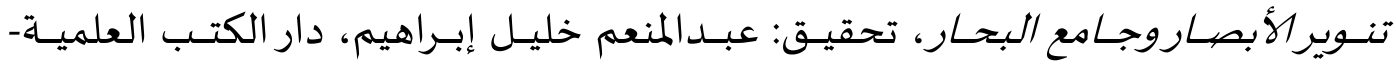

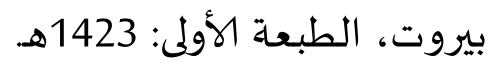

محمـد بـن محمـود بن أحمـد البابرتي، الـردود والنقـود شــح مختصـر/بن الحاجب، تحقيق: د. ضيف الله بن صـالج بن عـون العمـري، ود. ترحيب بن ربيعان الدوسـري، مكتبـة الرشـدــ الرياض، الطبعاة الأولى: 1426هـ

محمد بن أبي بكر بن أيوب بن سعد شسمس الدين ابن قيم الجوزيـة، زاد المعاد في هدي خيز

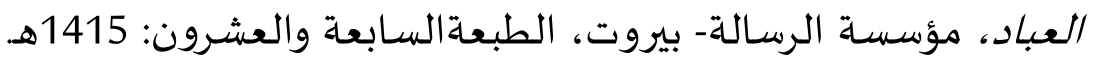

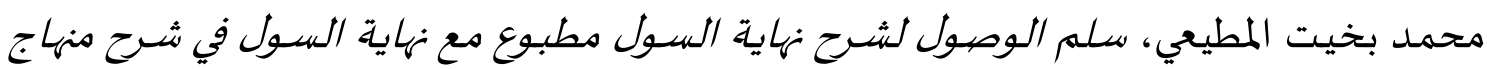
الوصول للإسنوي، عالم الكتب.

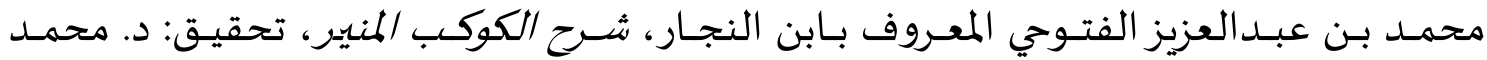

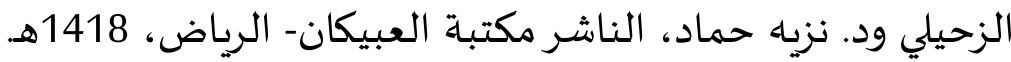

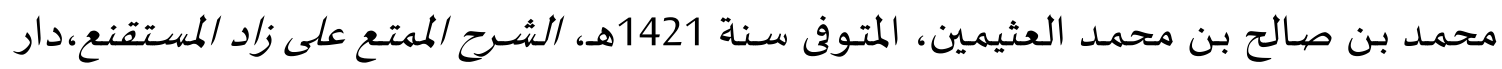
ابن الجوزي، الطبعة الأولى: 1422هـ.

نجم الدين أبي الربيع سليمان بن عبدالقوي الطوفي، شسرح مختصر الروضية، تحقيق: د. عبدالله

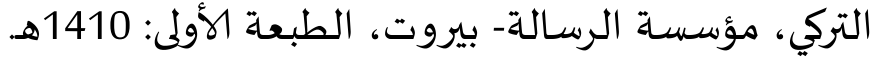
محمد بن عبدالله الخرشي المالكي المتوفى سنة 1101هـ، شَح مختصرخليل، دار الفكر للطباعةبيروت. 
HAYULA:Indonesian Journal of Multidisciplinary Islamic Studies, Vol. 2, No.2, Juli 2018 DOI:https://doi.org/10.21009/hayula.002.2.05

محمد بن محمد بن محمود، البابرتي ، العناية شرح الهد/ية ،دار الفكر - بيروت. محممد بن مفلح بن محمـد بن مفرج، أبي عبدالله، شـمس الدين المقدسي الرامينى ثم الصـالحي

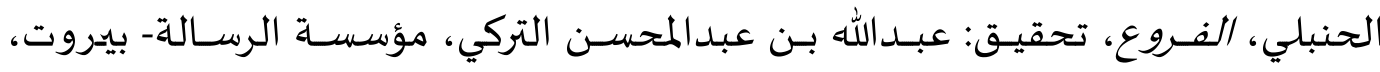
الطبعة الأولى: 1424هـ.

محب الله بن عبدالشكور البهاري، لعبدالعلي محمد بن نظام الدين الأنصياري، فـواتح الرحموت

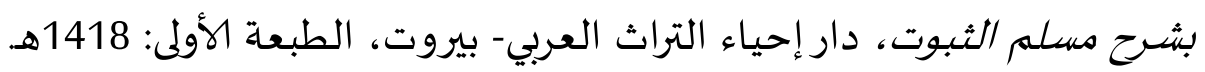
محمد بن يعقوب الفيروزآبادي، القاموس المحيط لمجبد الدين، تحقيق: مكتب التراث في مؤسسـة الرسالة بإشراف محمد نعيم العرقسوسي، ط5، بيروت، مؤسسـة الرسالة، 1416هـ محمد بن أحمد بن جزي الكلبي الغرناطي،قوانين الأحكام الشرعية ومسائل الفروع الفقهية، دار الأقصر، تحقيق: عبدالرحمن حسن محمود، الطبعة الأولى: 1405هـ. محمـد بـن أحمـد بن أبي سهل شـمس الأئمة السرخسي، المبسـوط، دار المعرفة - بيروت، تاريخ النشر: 1414هـ

محمــ بـن أبي بكـر بـن عبـدالقادر الـرازي، مختـار الصسحاح، دار الفكر العربي- بيروت، الطبعـة الأولى: 2002م.

محمـد بـن أبي بكر بـن أيـوب بـن سـعد، شـمس الـدين، ابـن قيم الجوزيـة،مــارج السـالكين بين

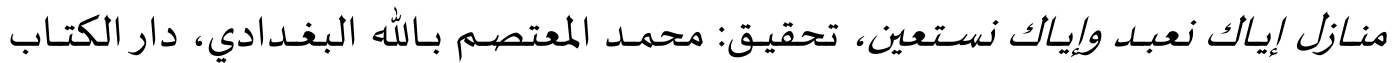
العربي- بيروت، الطبعة الثالثة: 1416هـ.

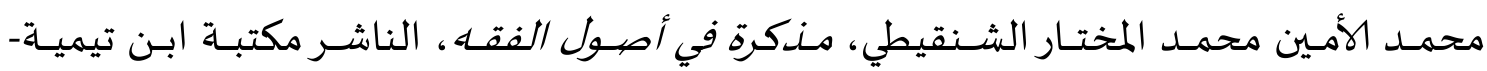
القاهرة، توزيع مكتبة العلم-جدة، الطبعة الثالثة: 1416هـ.

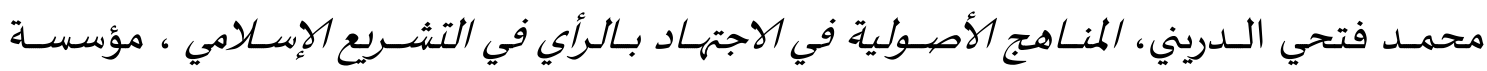
الرسالة- بيروت، الطبعة الثالثة: 1418هـ.

محمـد بـن أحمـد بـن محمـد عليش، أبي عبـدالله المالكي، منتح الجليل شــح مختصير خليل، دار

$$
\text { الفكر - بيروت، 1409هـ. }
$$

محمد الأمين بن محمد المختار الشنقيطي، نثير الـورود على مراقي السعود، تحقيق وإكمال تلميذه

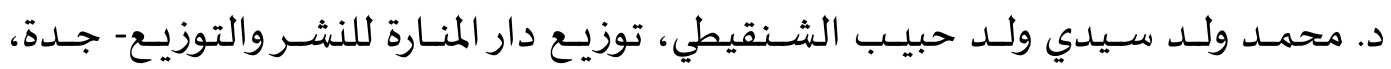
الطبعة الثانية: 1420هـ.

منصور بن يونس بن صلاح الدين ابن حسن بن إدريس البهوتي الحنبلي، كثاف القناع عن متن الوقناع، دار الكتب العلمية- بيروت.

مصـطفى بـن سـعد السـيوطي الرحيبـاني، مطالسب أولي النهىى في شــح غايـة المنتـهى، المكتـب 


$$
\begin{aligned}
& \text { الإسلامي- دمشق، 1961، } \\
& \text { النظر أبي بكر محمد بن أحمد السـمرقندي، ميزان الأصهول في نتائج العقول (المختصر)، تحقيق: } \\
& \text { د. محمد زكي عبدالبر، مكتبة دار التراث- القاهرة، الطبعة الثانياة: 1418هـ. }
\end{aligned}
$$

